$$
\begin{aligned}
& \text { قضية تجلديل الخطابالايني } \\
& \text { ( التجد يلد في مجال التفسير والدراساتالقرآنية) } \\
& \text { بحث مقدم ضمن مجموعة من الأبحاثالعلمية } \\
& \text { تنيل درجة أستاذ مسا عد في اللفة العربية } \\
& \text { والدراسات الإسلامية } \\
& \text { الدكتور / محمـل إبراهيـم أحمـلد رجسب } \\
& \text { مدرس منتدب بكلية التربية جامعة الأسكندرية } \\
& \text { فرع مطروح }
\end{aligned}
$$




\section{قال تعالي:}

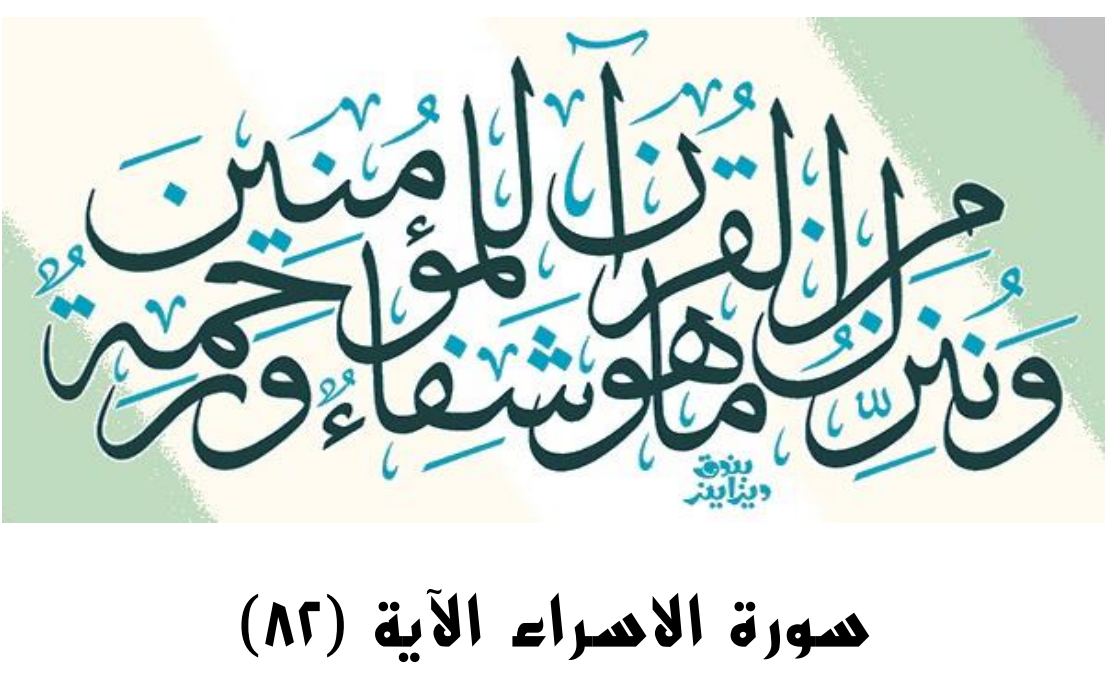


قضية تجلديل الخطاب الليني ( التجليد في مجال التفسيروالدراسات القرآنية )... قضية تجديا الخطاب الدينى

\section{التجديد فى مجال التفسير و الاراسات القرانية}

الهدف من البحث : المشاركة فى رسم خطة للتجديد فى مجال التقسير وعلوم القران و الدراسات القرانية عناصر البحث

1- - معنى التجديد - مصطلحات البحث - انواع الخطاب الدينى

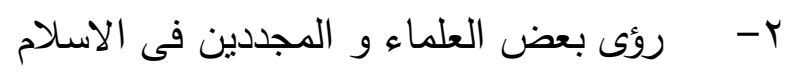

r- استتباط الاحكام التشريعية من القران الكريم و دور التفسير فيها ع - المسيرة التجدية للخطاب الدينى عبلر تاريخ الاسلام - - - التدرج التاريخى لقضية تجديد التفسير ؟- - دور المستشرقين فى تجديد التفسير القرانى - - - التجديد فى الدراسات القرانية و منها علوم القران

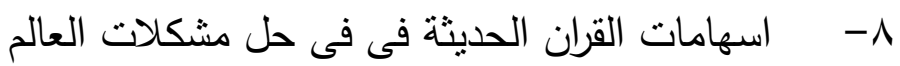
خطة البحث

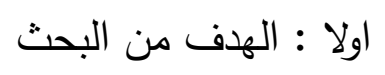

ثانيا :يتكون من ثلاثة فصول و كل فصل يشتمل على عدة مباحث

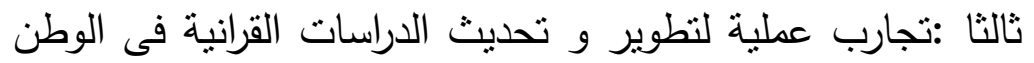

$$
\text { العربى الخاتمة و التوصيات }
$$

1 - يهدف لتطوير مجالات التفسير و علوم القران و الدراسات القرانية

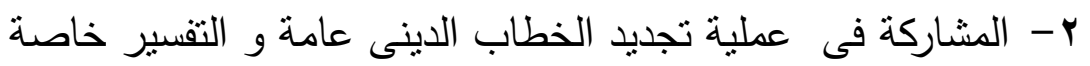


مجلة كلية الدراسات الإسلامية والعربية للبناتبكفر الشيخ العددالثاني - المجلد السادس لعام ما.rم

\section{RENEWAL OF RELIGIOUS SPEECH ISSUE}

Renewal in the field of interpretation and Quranic studies

THE AIM OF THE RESEARCH: Participating in drawing up a plan for renewal in the field of interpretation, Quranic sciences and Quranic studies

\section{SEARCH ELEMENTS}

1- Meaning of renewal - search terms - the types of religious speech

2 - visions of some scholars and innovators in Islam

3 -the assumption of legislative provisions from the Koran and the role of interpretation

4-The Renewal Process of the Religious Speech through History of Islam

5-Historical hierarchy of the issue of renewal of interpretation

6-The role of orientalists in the renewal of the Quranic interpretation

7-renewal in the studies of the Koran, including the Koran sciences

8 - Contribution of modern Quran in solving the world's problems

\section{SEARCH PLAN}

First: The purpose of the research

Second: It consists of three chapters and each chapter includes several topics

Third: Practical experiments to develop and update Quranic studies in the Arab world

\section{CONCLUSION AND RECOMMENDATIONS}

1-Aiming to develop areas of interpretation and the sciences of Quran and Quranic studies

2-Participation in the process of renewal of religious speech in general and interpretation in particular 


\section{المقدمة}

بسم الله الرحمن الرحيم

الحمد لله رب العالمين والصلاة والسلام علي أشرف المرسلين وخاتم النبيين محمد صلي الله عليه وسلم ومن تبعهم بإحسانه الي يوم الدين ...وبعد.

كتير من العلماء من ينادي بتجديد الخطاب الديني ، ويذهب كل واحد للتجديد حسب وجهة نظره ورؤيته ، فمن يضع قواعد وأسس للتجديد ويسير علي هذه القواعد والأسس فيصل إلي نتيجة طيبة يساهم في إثراء الحياة العلمية والدينية والثقافية ومنهم من يبالغ ويخلي في نظرية للتجديد فيأني بالعجب العجاب من الأفوال والأفكار التي تهدم وتضع سياجا حاكما علي العقل والقلب وبين هذا وذاك : توجد طائفة من العلماء تأخذ لنفسها خطا وسطاً يجمع بين الأصالة والمعاصرة ،بين القديم ومتطلبات

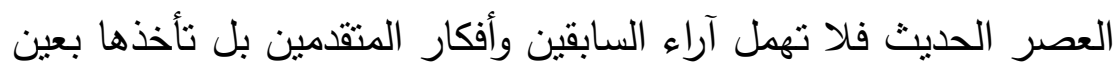
الإعبتار والإنصاف ،وتضيف عليها بما يتماشي ويحتاج إلية الناس في الأزمنة المتأخرة والأيام المعاصرة وهذه الطائفة هي التي يكتب لها البقاء ويستمر منها العطاء ل،ها هي التي احترمت القديم وقدرت الجديد . ومن خلال تخصصي العلمي والديني قمت بدارسة عن( تجديد الخطاب الديني ) وأخذت مثالا علي هذا التجديد وجعلت عنوانه: (التجديد في مجال التفسير وعلوم القرآن والدراسات القرآنية). وقمت بجمع أراء السابقين ورؤية المعاصرين وزاوجت بين الرؤينتين وخرجت بروية تجمع ولا تقرق وتبني ولا تهدم. 
وكان هدفي من هذه الدراسة الإسهام بقدر ولو بسيط في تجديد

الخطاب التفسيري وعلوم القرآن والمشاركة في الدراسات القرآنية ، وفتح باب لبعض الباحثين الجادين في إستكمال هذه الرؤية أو القاء مزيداً من فن الضوء عليها ، وتطبيقها في الحياة المعاصرة ليستفيد منها المسلم المعاصر

ويزداد الإرتباط بين القرآن الكريم والتفاسير والتمسك بالأراء الصائبة

والبعد عن الأراء الثاذة والباطلة ، والوقوف في وجه بعض الفرق الضالة ومحاولتها جر النص الديني ( قرآن أو سنة أو تفسير علماء ) لتبرير اقوالهم وأفعالهم الفاسدة.

وأخيراً : إبراز عطاء النص الديني المتجدد علي طول الزمان ،

وجذب الناس إلي حدائق الإيمان والبعد عن جزر الإلحاد والذي أصبح ينتنر في كثير من بلاد العالم المتدين وغير المتدين ، وأفكار وجود الإله الخالق المدبر الصانع لهذا الكون العظيم

فإن كنت قد أصبت في إبراز هذه الرؤية فهذا من فضل الله وكرمه

وإن كنت قد أخطات فهذا من نفسي ومن الثيطان ولا ألوم إلا نفسي :

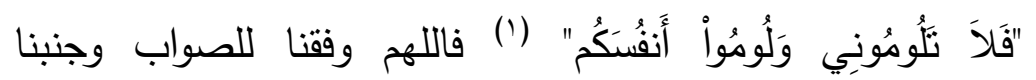

$$
\text { إغواءات النفس والثيطان. }
$$

وآخر دعوانا أن الحمد لله رب العالمين

(1 ) سورة إبراهيم الآية رقم (r ( ) 


\section{الأدف من الرسالة}

(1)- التأكيد علي أن التجديد بالمفهوم الثرعي الصحيح أمر مطلوب التباله وملح وهو أمر شرعي ، وهو مطلب لكل مسلم صادق غيور علي

$$
\text { هذه الأمة. }
$$

(Y) - إن دارسة التفسير وعلوم القرآن بالمنهج القديم أصبح لا يجدي نفعا والها

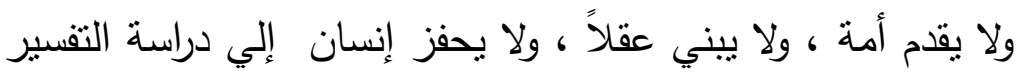
وعلوم القرآن.

(r)- ليس بالضرورة أن تجمع تفاسير العصر علي منهج واحد ، وروح واحدة ، إذ حاجة الأمة تستوعب التتوع ، والإختلاف بين التهاسير المفسرين

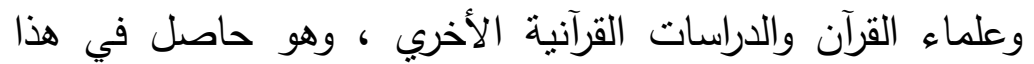
الميدان.

(ع)- لابد من مواكبة التقسير لحاجات العصر بحيث ينطلق لإصلاح

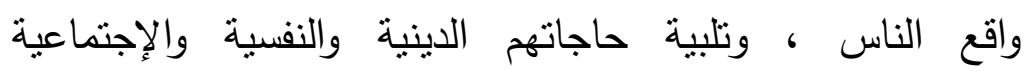

$$
\text { والإقتصادية...الخ. }
$$

(0)- الوقوف في وجه الحركات الفكرية والتيارات العلمانية ومحاولتها جر النص القرآني لتفسيراتها الثاذة والبعيدة عن روح النص النص القرآني ومباديء الإسلام الحنيف ، ومحاولة شرذمة - منهم - تريد تأويل النص القرآني حسب أهوائهم وأهواء من يسايرهم من أعداء الإسلام والمسلمين. (7) - إن موقع النص القرآني - في أمة الإسلام - بكل طوائفها ومذاهبها

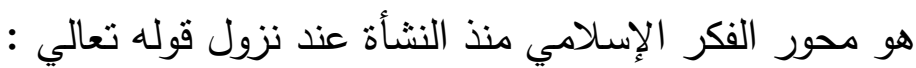

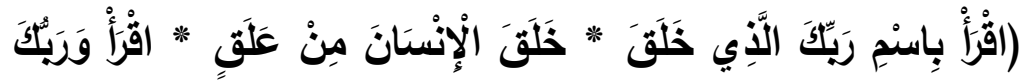

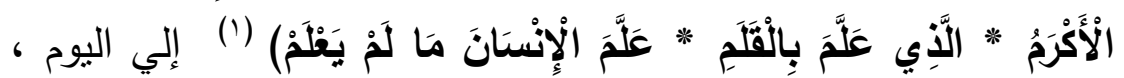


وكل ما أنتجه الفكر الإسلامي لايعدو أن يكون مؤيداً للنص او مسـاعداً علي فهمه او استتباطاً منه.

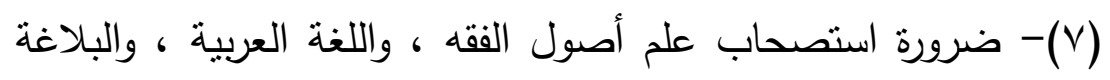

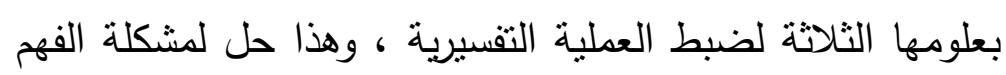
اللغوي الخاص للاليل الثرعي ، سواء من حيث مقاصده الدلالية، أو متعارضاته الإثكالية (')

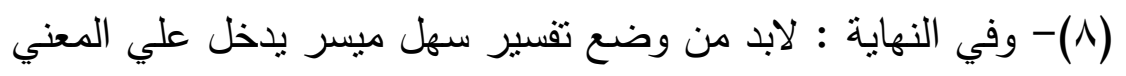

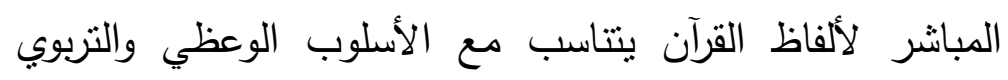
والفقهي والعلمي في وقت واحد ، والخروج بمواضيع علوم القرآن عن القوالب السابقة وتسهيلها بما يجذب إليها قلوب وعقول الكبار والصغار وغرس الإيمان في قلوب المؤمنين وربطهم بكتاب رب

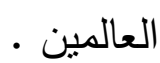
وأخيراً وليس آخراً إن كنت قد اصبت في ماكتبت من أفكار ورؤي

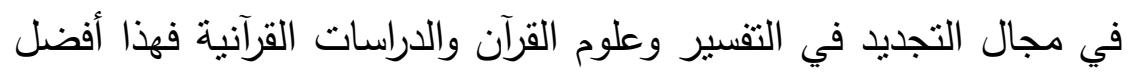

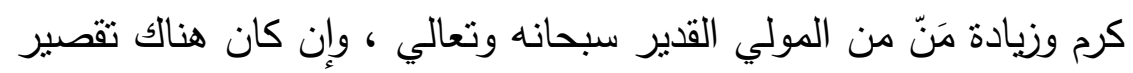

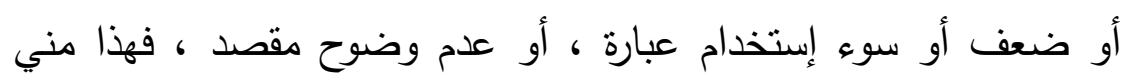
ومن الثيطان فاسأل اله تعالي قبول المغفرة وغفران المذلة وأن يلهينا الصواب وحسن البيان إنه ولي ذلك والقادر عليه. وآخر دعوانا أن الحمد لله رب العالمين

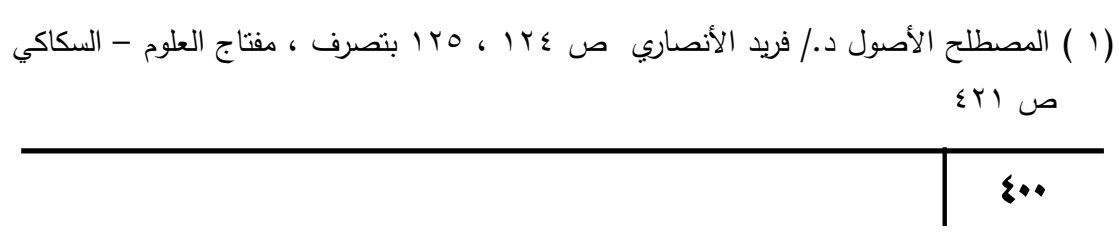




\section{تخريج حليث التجديا}

قال أبو داود : حدثنا سليمان بن داود المهري أخبرنا ابن وهب دابت

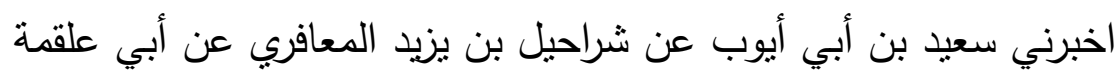
عن أبي هريرة رضي الله عنه فيما أعلم عن رسول الله عليه وسلم قال:

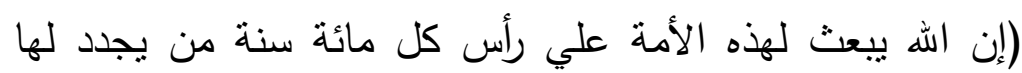

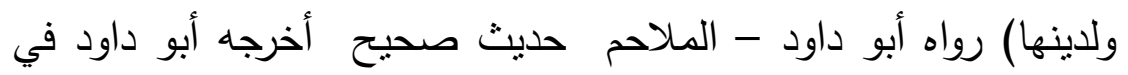

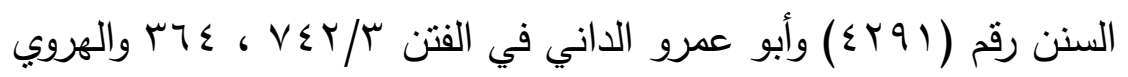

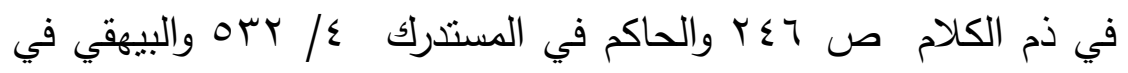

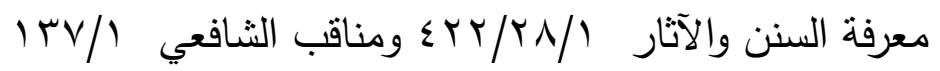

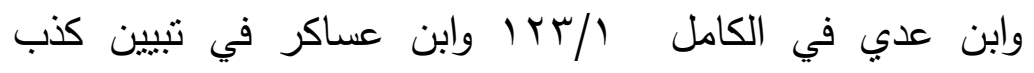

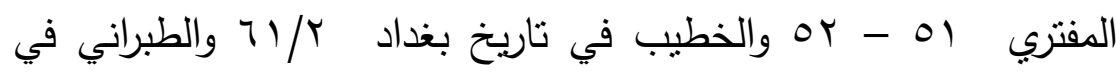

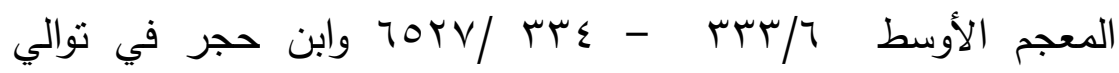
التأسيس بمعالي إدريس ص ص اء عن طرق عن ابن وهب : أخبرني سعيد بن أبي أيوب عن شراحيل بن يزيد العافري عن أبي علقمة عن أبي

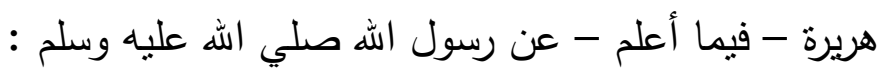

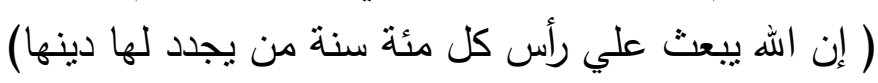

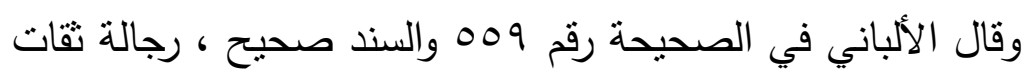

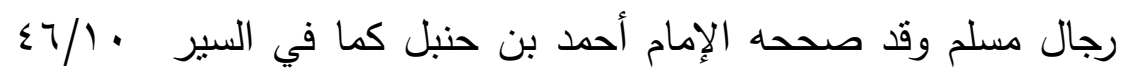
والله أعلم. 


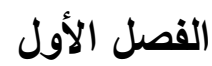

\section{( ) معني التجديد:}

كما جاء في توصيات مؤتمر (التجديد في الفكر والعلوم

$$
\text { الاسلامية): (ل) }
$$

"إن التجديد هو خاصة لازمة من لوازم دين الاسلام، نبه عليه

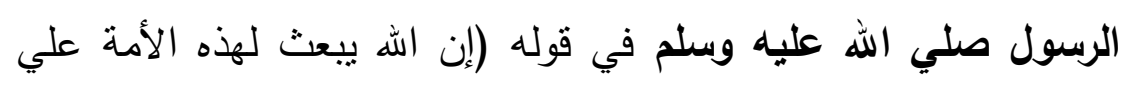

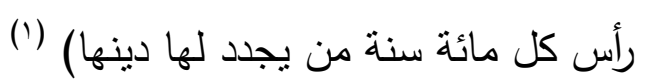

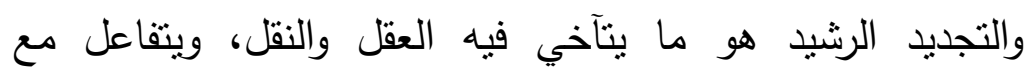
المنطلبات المجتمعية والدولية.

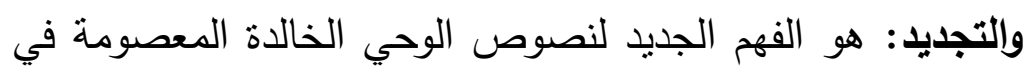

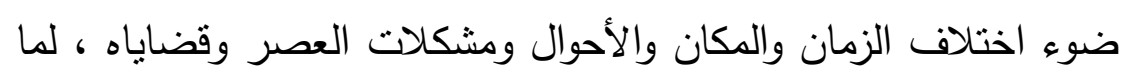

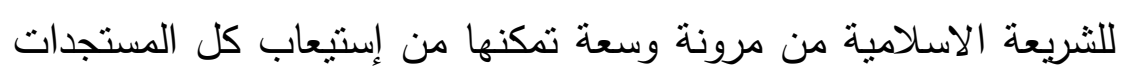

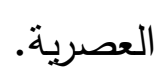

والتجديد لا يعني الإلغاء ولا التبديل ولا التبديد، ولا الكساس بالثوابت والمسلمات ، ولا إهدار ما بذله المجتهدون عبر القرون، فاجتهادهم يمثل ولاهل

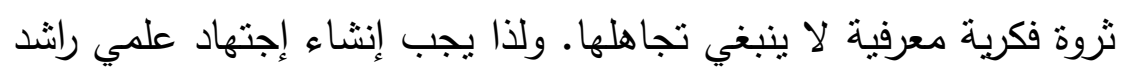

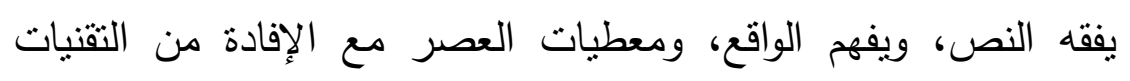
الحديثة (r)

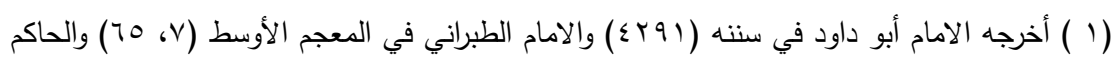

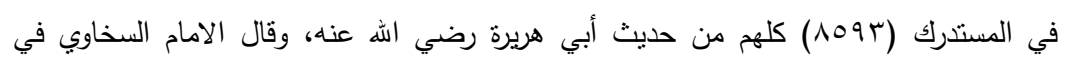

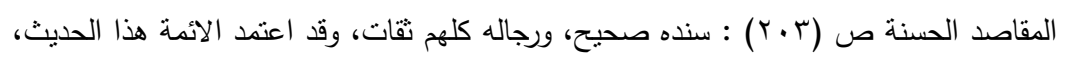

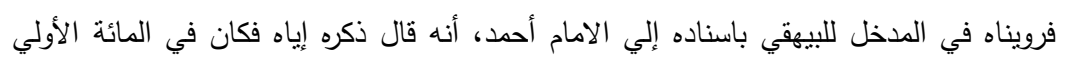

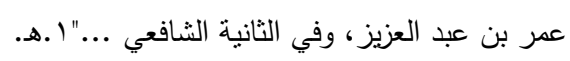

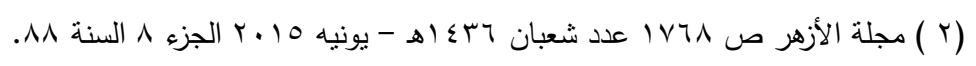


المراد بالمجدد: هو عالم دين يبعثه الله علي رأس كل مائة سنة ليجدد للناس دينهم عن طريق القيام بأعمال جليلة ، ونشر العلم الديني بين الناس، بالإضافة إلي إحياء سنة الرسول صلي الله عليه وسلم، والرد ومحاربة البدع المنتشرة بين الناس في زمانه.

ويقصد بالتجديد: إعادة الدين إلي ما كان عليه في أول عهده ، ويعني هذا أن الدين كان تاماً ومكتملاً ثم أخذ يعتريه النقص وذهب أكثان أكثره، فأعاده هؤلاء المجددون إلي قريب من حالته في عهد السلف الأول.

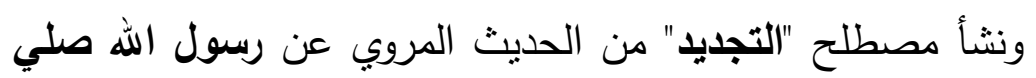
الله عليه وسلم، وقد ادعي كل قوم (علم) في إمامهم أنه المراد بهذا الحديث؛ والظاهر والله أعلم أنه يعم حملة العلم من كل طائفة، وكل صنف من أصناف العلماء ، من مفسرين، ومحدثين، وفقهاء، ودعاة، ولغوبين إلي غير ذللك من الأصناف".

(r) تحديد المفاهيم والمصطلحات ودورها في تجديد الخطاب الديني كلمة \}الخطاب الديني\{ من الكلمات التي شاعت علي ألسنة دعاة التجديد والتحديث علي إختلاف توجهاتهم، وتتوع أهدافهم، وانتشرت علي ألسنة المثقفين، وفي وسائل الإعلام، مرئية ومسموعة ومقروءة، وفي أدبيات دعاة الإصلاح بوجه عام. فالكلمة معروفة ومتداولة ومألوفة بين الناس، ولكنها غير محددة الأبعاد، غير معلومة في استخداماتها ومالآتها. فالواجب الثرعي يحتم علينا تحديد المفاهيم. وما أكثر المفاهيم المغلوطة التي اعترت خطابنا الديني علي أبدي فئة متتددة أو جاهلة أو مغرضة لا تملك من أدوات العلم ما يؤهلها لذلك، واستخدمها لمفاهيم مثل الجهاد والخلافة والحاكمية ومفهوم دار الاسلام والحرب والجردية 
ووضع غير المسلمين في البلاد الاسلامية والأقليات المسلمة في بلاد الغرب.

فأصبحت هذه المفاهيم من أدبيات الخطاب الديني المتتدد الذي

أساء إلي الاسلام إساءات بالغة، وعلماء الازهر بشتي تخصصاتهم الدينية والعربية معنيون بتجديد هذه المفاهيم وتوضيح المفهوم الصحيح لها وابراز الوجه الذي تقصده الأدلة الثرعية ، فمتي قام علماء الأزهر الثربف بهذا الدور يكونون قد قدموا خدمة جليلة للاسلام ولتراث الإسلام. وعند هذا الحد لابد أن نعرف ما المقصود بالخطاب الابني؟ فنقول وبالله التوفيق : المقصود بالخطاب الديني: هو النتاج الفكري، والثروة العلمية والفقهية التي تركها لنا الائمة العظام ممن قدحوا زناد الفكر ، وتأملوا وتدبروا في نصوص الثربعة الإسلامية فاستتبطوا منها هذه المفاهيم المتعددة، وتلك القضايا الوافرة. فالمقصود بتجديد الخطاب ليس هو النصوص الثرعية من الكتاب والسنة الصحيحة التي ثبت نقلها عن المعصوم صلي الله عليه وسلم، وإنما المقصود هو كتب الفقهاء والعلماء والمحدثين والمفسرين وأهل اللغة وغيرهم من الشروحات والتعليقات التي سجلها هؤلاء العلماء من خلاء استتباط هذه القضايا من نصوص الكتاب والسنة الصحيحة. ( أنواع الخطاب الايني الخطاب الايني يتعدد ويتنوع إلي عدة أنواع وهي: 1- الخطاب الديني المتشدد. r- الخطاب الديني الوسطي. r- الخطاب الديني المتساهل. 
أولاً: الخطاب الديني المتشدد.

هو الخطاب الذي تتبناه بعض الجماعات المتتددة والمتطرفة التي

تجعل من الحرام والتحريم والتجريم عنوان للفتوي ولوجهة النظر التي تتبناها فتري الفتوي المتشددة ووجهة النظر المنحرفة التي تأخذ بالناس إلي أقصي اليمين المتطرف مما يجعل الناس تثٔن من هذه الفتوي ولا تستطيع تطبيقها

أو العمل بها لمخالفتها لسماحة الاسلام ويسره وعدم تماشيها مع الفطرة الانسانية البسيطة مثل فتوي جماعات التكفير والهجرة. وتتظيم "داعش" الارهابي الذي يتلذذ بتحطيم الآثار وهدم المعابد والتراث الحضاري والمعماري والثقافي في قتل المغايرين له في الدين أو وجهة النظر أو الفكرة كقتل المسيحيين والأيزيدين ، بل وبعض طورئف وائف أهل السنة كما يحدث في بلاد العراق والثام وغيرها من البلاد ويدعون تمسكهم بالمنهج السلفي ، بل نجد بل الطوائف الثيعية تتفن في قتل وايذاء بعض أهل السنة ونصب العداء لهم علي طول الخط. ويذهب هؤلاء المتتدددون إلي النصوص القرآنية والحديثية وبستخرجون منها تأوبلات متتددة ومتطرفة ويجعلون مستتدهم هذه النصوص مما يجعل الناس في حيرة من أمرهم وتذبذب في تفكيرهم من أين أتوا بهذه التفسيرات والتأويلات المتشددة ؟ فيبثون في نفوس الناس الخوف والارهاب مما جعل المسلمين يخافون من تطبيق شرع اله في حياتهم وأورث مفهوم (الاسلام فوبيا) عند غير المسلمين خوفاً وأوجد حاجزاً نفسياً واجتماعياً بعدم قبول المسلمين وقبول الاسلام في المجتمعات غير المسلمة وأقصد بها (المجتمعات الغربية) ودور هذه الجماعات في تشويه الخطاب وهذا ما جعل كل واحد من هؤلاء يريد الثهرة أو الظهور 
أن يذهب ويأتي بفتوي منتددة أو منطرفة فتتار الأقاويل وتتعدد الأراء بين مؤيد ومعارض فيشتت جهد المسلمين ويستتف طاقة المخلصين. ثانياً: الخطاب الديني الوسطي. هذا الخطاب الديني هو الخطاب السائد في بلاد الاسلام والمسلمين

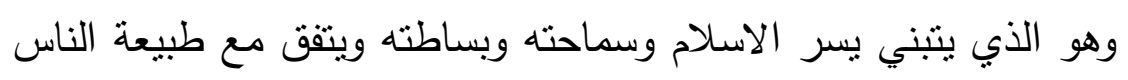
وحياتهم العملية والعلمية.

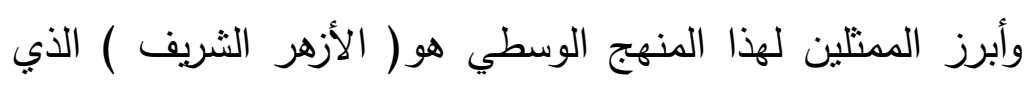

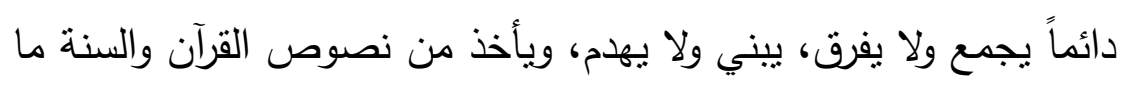

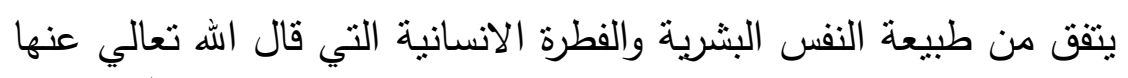

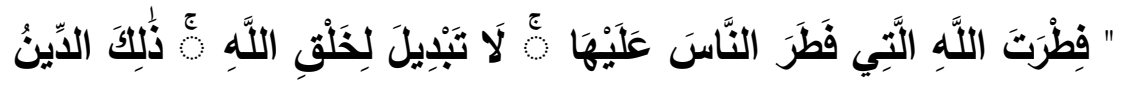

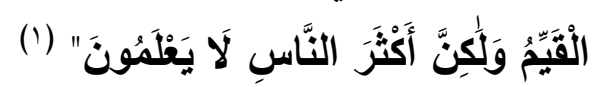

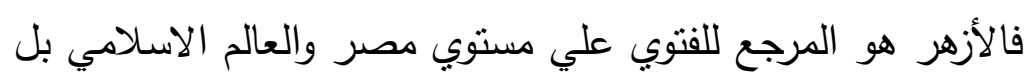

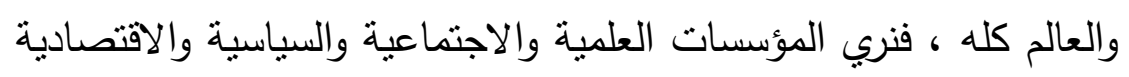
ترجع إلي الأزهر لأخذ الحكم الثرعي والبيان الفقهي لكثير من المسائل

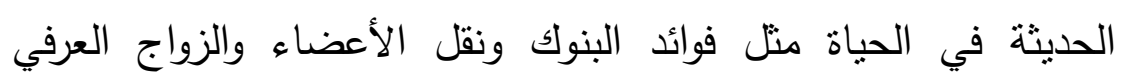

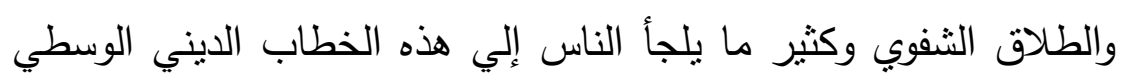

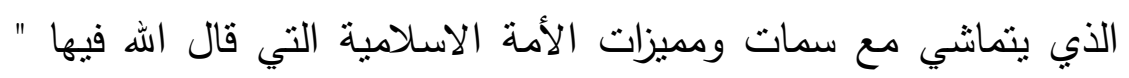

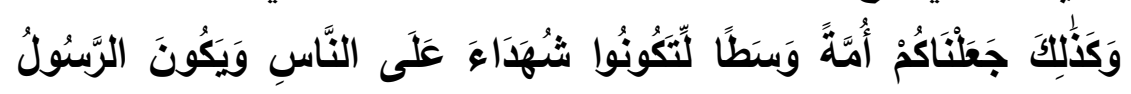

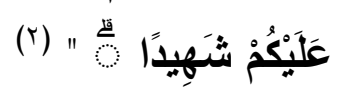




\section{قضية تجليد الخطاب اللديني ( التجليد في مجال التفسير والدراسات القرآنية )...}

وغيرها من المسائل التي يجد الناس فيها الراحة النفسية

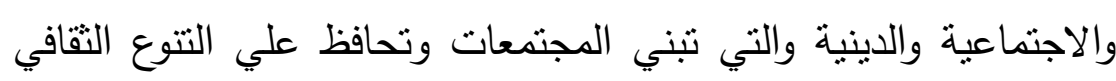

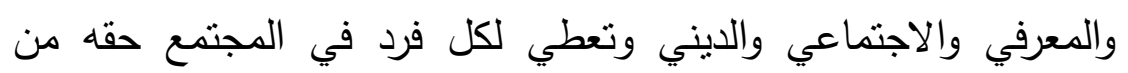
الحقوق وتطالبه بأداء الواجب المفروض ولائي وتعبيه.

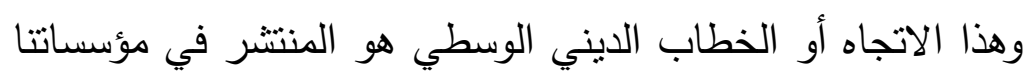

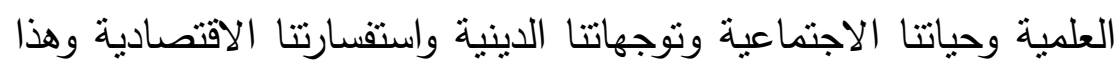

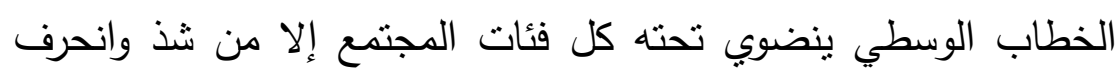
وابتعد وذهب إما إلي التتدد وإما إلي التساهل.

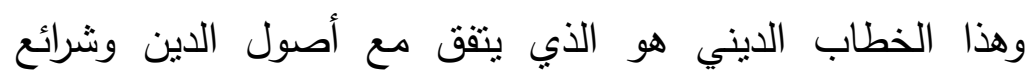

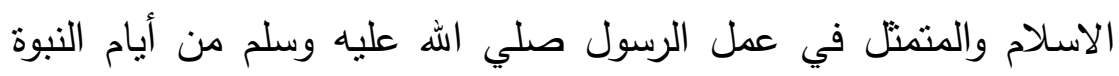

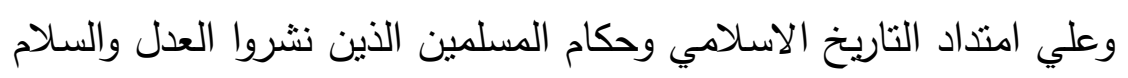
والمحبة بين المجتمعات الانسانية.

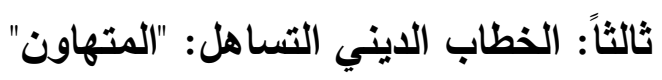
هذا الخطاب الذي يتبناه كل جاهل وعديم المعرفة ومن أخذ شيئاً بسيطاً من العلم فذهب يريد أن يفتي الناس بهذه الفتاوي المسهلة

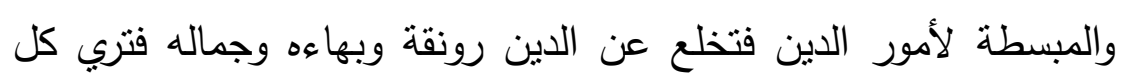

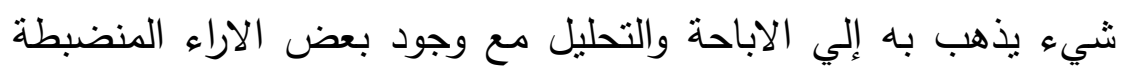
التي تمنع أو تجرم - بالجيم - منل هذه الأفعال.

ويستحين هذا الجاهل انصاف المتعلمين في الدفاع عن وجهة نظره

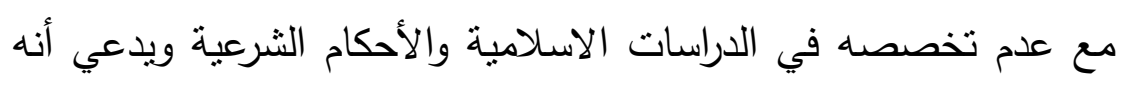

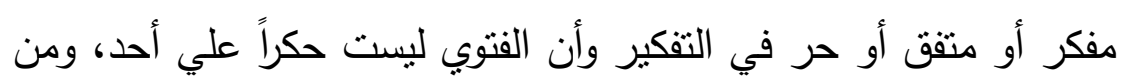

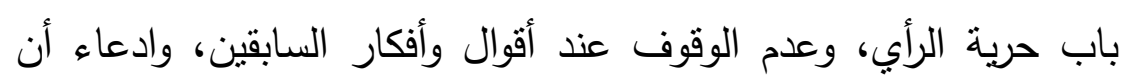
القديم لا يتفق مع روح العصر ومستجدات الحياة. 
ويمنل هذه الطائفة بعض المفكرين - كما يسمون أنفسهر - من

العلمانيين والتتويرين والثيوعيين وأصحاب الفكر الحر أمثال "اسلام

بحيري. في مصر" "وخالد منتصر في مصر" ومحمد اركون في بلاد المغرب العربي - وبعض الأعلاميين والاعلاميات علي شيري ماشات الفضانيات ومواقع التواصل الاجتماعي. وهؤلاء خطرهم شديد لتواجدهم الاعلامي ولظهورهم الدائم وقوة تأثير الاعلام علي الحياة المعاصرة. بل وهول نجد بعض نجوم الكرة والفن يجلس ويتكلم في الحلال والحرام والجائز والممنوع مع جهلة الواضح وغبائه الناضح فهو لا يعرف من الدين إلا القليل ولا من اللغة العربية إلا البسيط.

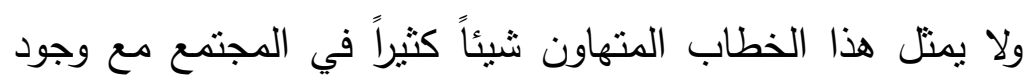
سطوته الاعلامية وذللك لسيطرة الخطاب الديني الوسطي. بعد هذه الجولة بين أنواع الخطاب الديني - حسب روئيتنا - نري أن الخطاب الديني الوسطي هو المسيطر علي المجتمعات الاسلامية ولكن يجب اعطائه مزيداً من القوة والحرية ليواجه التيار المنتدد ويقلل البطي من تأثير الخطاب المتساهل لأن خير الامور الوسط "وما خير الرسول صلي الله عليه وسلم بين أمربين إلا أختار أيسرهما ما لم يكن أثنا , , (1) كما في حديث عائشة رضي الله عنها.

\section{(ع) الاراسة العملية للتجديد في مناهج المفسرين وتفاسبرهم}

لابد من الاتفاق علي الاقرار بأن الاقتصار علي إعادة كلام

السابقين - عليهم رحمة الهه - دون زيادة عليه هو تعطيل لفيض وعطاء

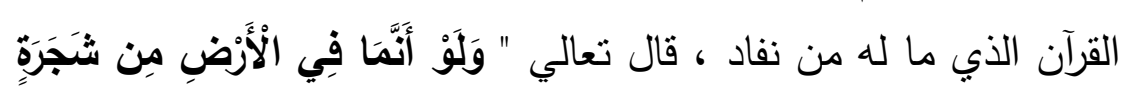

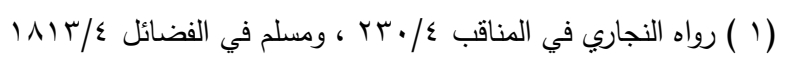




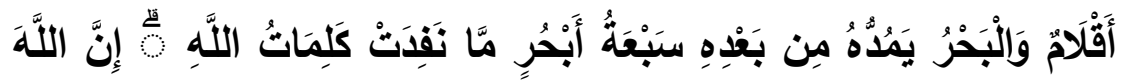

عَزْيزٌ حَكِيمٌ "(1)

وكما جاء في حديث النبي صلي الله عليه وسلم في وصف القرآن:

"ولا يخلق علي كثرة الرد".(r) (r)

يقول أ.د/ عبد الفتاح عبد الغني العواري. لري.

والناس إزاء كلام الأقديين - السابقين - رحمة الله عليهم - أحد

رجلين:

الأول: رجل معتكف فيما شاده الأقدمون.

والآخر : رجل آخذ بمعوله في هدم ما مضت عليه القرون.

وفي كلتا الحالتين خطر جسيم وضرر كبير •

فماذا نصنع في مجال التجديد في مناهج التفسير حتي لا نكون أحد وفر هير

ذينك الرجلين؟

وإنا بدوري - في هذا البحث - أتبني نفس فكرة الدكتور / عبد الفتاح

العواري وهي الحالة الثالثة والتي تقدر جهد السابقين وتتعامل مع عطاء

واجتهاد المعاصرين.

فنقول : إنتا نمثل

حالة ثالثة ينجبر بها الجناح الكسير ، وتتمثل هذه الحالة في أن نعمد إلي ما شاده الأقدمن فننظر فيه بالتهذيب والزيادة والثرح والتوضيح

rv / لقمان (1)

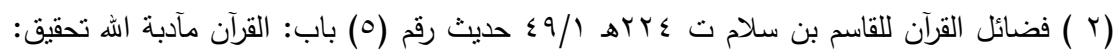

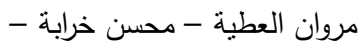

وفاء تقي الدين دار بن كثير - دمثق - بيروت . بـ أهـ من حديث عبد الله بن مسعود، سنن

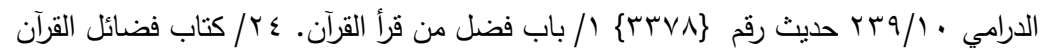


وإزالة ما علق به من شوائب ، وماطراً عليه من الاخيل، حتي نبرز للناس الأصيل في التفسير فتتجلي زبدة الحق الصراح وتذهب رغن رغوة الباطل. وقد قام بعض العلماء الأجلاء بعمل مثل هذه المشاريع فنقت التفسير من الاسرائيليات والموضوعات والدخيل ومن أبرزهم الأستاذ

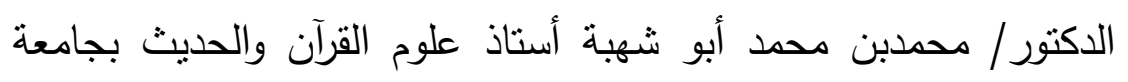
الأزهر وأم القري في كتابه الماتع "الاسرائيليات والموضوعات في كتب لتبن التفسير" فمن يقرأ في هذا الكتاب يجد محاولة ممتازة وسباقة في مجال تجديد النظرة لكتب التقسير وعلوم القرآن فقام بإظهار بعض الاسرئيليات والموضوعات التي دست في كتب التقسير منل المائدة التي طلبها الحواريون وذي القرنين وملكة سبأ وقصة سليمان وأيوب وأصحاب الكهف وألواح التوراة وغيرها من الموضوعات التي عالجها هذا العالم الكبير فكان

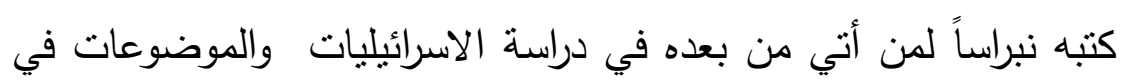
كتب التفسير . وكتاب " الصحيح المسند في أسباب النزول" للدكتور/ مقبل بن هادي الوادعي فقد قام بدراسة مستقيضة وأثبت صحة بعض الروايات الواردة في اسباب النزول ورد الضعيف والموضوع من أسباب النزول وهذا

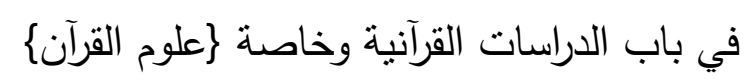

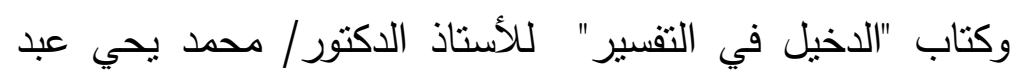
المنعم (رحمه الله) عميد كلية أصول الدين والدعوة الاسلامية بالمنصورة - جامعة الازهر - فقام برد وأبطال وتصحيح كثير من الروايات الضعيفة والموضوعة التي احتوت عليها بعض كتب التفسير وعلوم القرآن وهو جهد مشكور وعمل متفرد ومتقدم في مجال التجديد في مجال الدراسات القرآنية وخاصة (التفسير) . 
وأعتقد أننا بهذا المنهج الوسطي للتجديد لا يمكن لأحد أن يتهنا بأننا نقضنا تراثتا أو أبدناه أو أهملناه ، بل خدمناه وهذبناه وجليناه، لأننا نؤمن بأن في النقد لتراث الأئمة غمض فضلهم ، وغمض فضل السابقين كفران للنعمة، وجحد لمزاياه ، وكلاهما ليس من حميد خصال هذه الأئمة

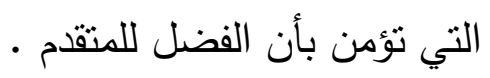
معاني التجديد:

والتجديد له معنيان: تجديد في التبليغ وتجديد في التأصيل؛ الأول: أما التجديد في التبليغ: فهو تطوير أسلوب تبليغ التفسير القرآني - بمعني أوضح - نقل النص الموجود في طيات أمهات كتب التفسير للغة وأسلوب يدركه المخاطب ،كما فعل الثيخ محمد منولي الثعراوي "رحمه الله" وهذا أمر واجب - في نظري - خدمة لكتاب الله تعاليّ. الثاني: أما التجديد في التأصيل: فهو محاولة زعزعة الثقة بموروث كتب التفسير واتهامها بالجمود ، والدعوة للتحرر منها ،بدون النظر إلي أهلية المفسر لهذا العمل. وهذا التجديد بهذا المنظور الثاني خطر كبير، ومؤامرة واضحة ، وحراس القرآن لن يسامحوا لمنل هذا الباب أن يفتح. كما حدث مع بعض المعاصرين الذي ذهب بشوه أقوال الطبري وابن كثثر وأبو حيان والقرطبي من المفسرين وغيرهم من أصحاب الحديث كالبخاري ومسلم فقوبل بهجوم حاد ودفاع مستميت عن علماء الحديث والتفسير ونال ما يستحق من جزاء.

وقد وضع بعض العلماء والمعاصرين المنهج القويم لمن يريد أن يقوم بهذا التجديد وهو شيخ البلاغيين المعاصرين للأستاذ الثيخ 
الدكتور / محمد أبو موسي - فإنه ألح علي هذه القضية في مؤلفاته وبيَّن

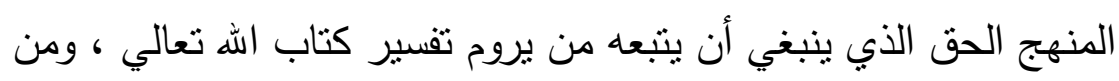

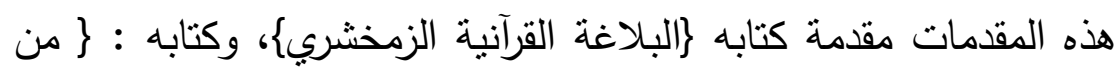

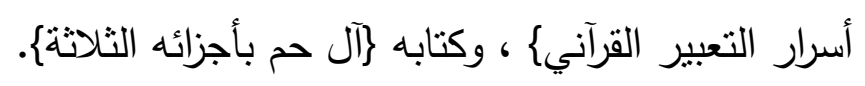

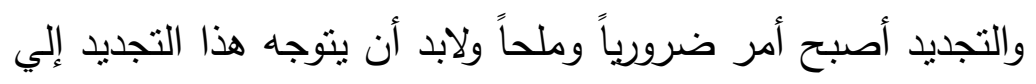

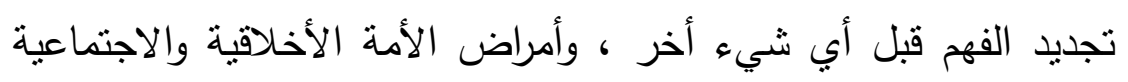

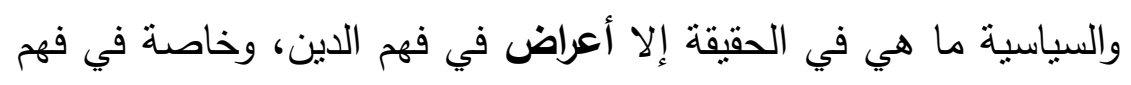
نصوص الثريعة قرآناً وسنة.

ولولا استشهدنا بقول ابن تيمية: (إن الكتب المصنفة في التقسير

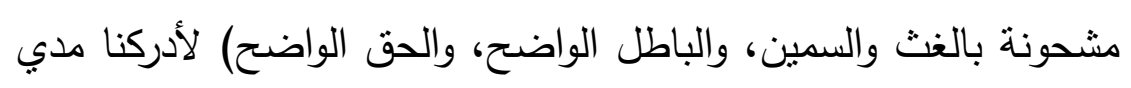

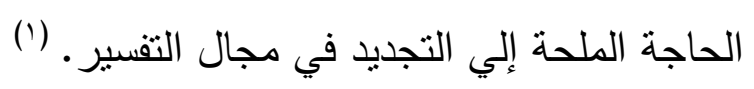

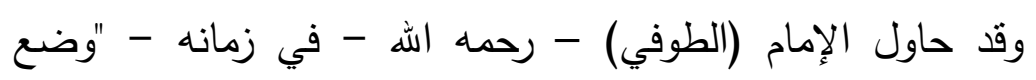

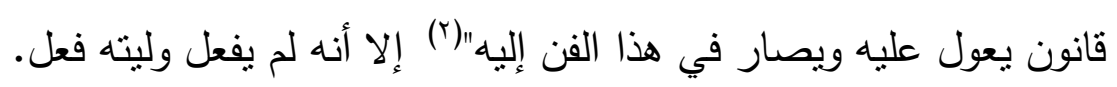

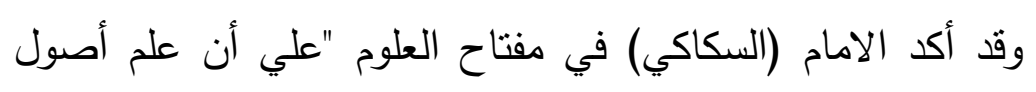

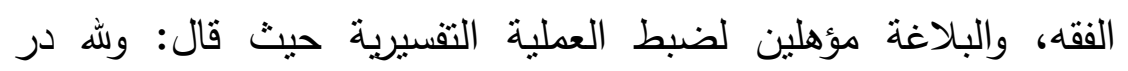

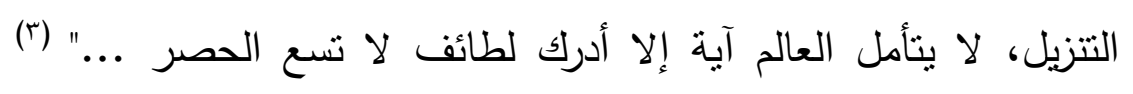

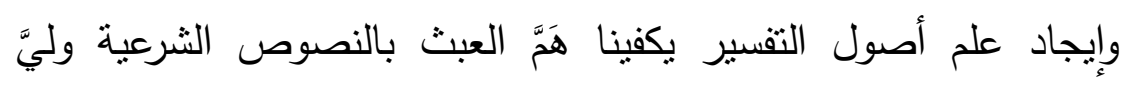

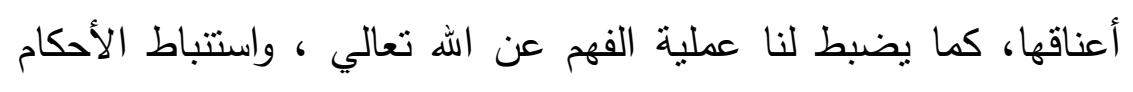

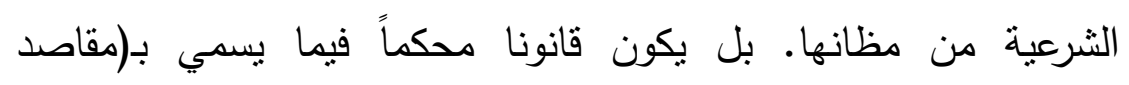
الثريعة) ذلك أن القصد يفهم من اللفظ، ومن النص الثرعي. فيجيينا علم

$$
\begin{aligned}
& \text { (1 ) مقدمة في أصول التفسير - لإبن تيمية صب (1) }
\end{aligned}
$$

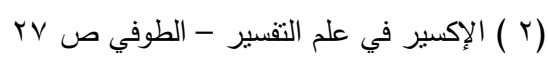

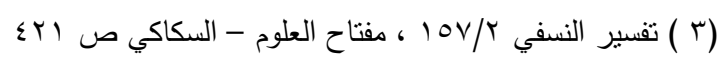


أصول التفسير عن السؤال العلمي: كيف دل هذا اللفظ أو هذا النص علي هذا المعني أو هذا الحكم؟

وقس علي ذللك من القضايا والمستجدات الطارئة علي الفكر الإسلامي اليوم، كمسألة السنن التاريخية والإجتماعية في القرآن الكريم، وقضايا التشريع الجنائي، والنوازل الفقهية في الطب وغيره. والله أعلم.

\section{التجديد دافع للتقييم والفرز والإلغاء والاضافة وبرة}

حينما يعمد الانسان إلي التجديد لابد أن يكون دافعه إلي ذلك هو

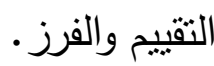

والإنسان الذي يقوم بهذا التقييم والفرز لابد أن يقف موقف الحكم بين طوائف العلماء، مجلياً مالهم تارة، وما عليهم تارة أخري بعيداً عن لإن المجاملة والتجني علي الآخر أو يكون مؤيدا لأحدهما علي حساب الأخر بسبب قرب ميله الفكري أو العلمي لأحدهما وبعده عن الأخر . وأن يقوم بفرز هذه الأقوال بمنهج علمي دقيق قائم علي المعرفة التامة والتجرد من الأحكام السابقة حتي يخرج عمله علي وجه من الكفاءة والقبول وجمع الأراء وليس تتنتيتها، وبلغي وبرفض من الأقوال ما يقبل الرفض والالغاء مع ذكر الأدلة التي حملته علي هذا الرفض والالغاء ، وإضافة ما يحتاجه التفسير لإبراز الوجه المشرق والمتجدد للتفسير مما يتتاسب مع مستجدات العلوم وعطاء الحضارات. إذا فعلي هذا الانسان الذي يقيم هذا التراث أن يتجرد من الأهواء

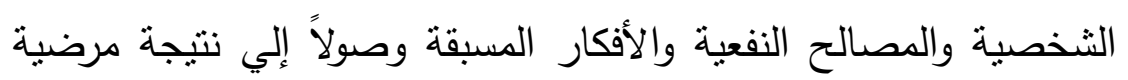
ومطمئنة ويجوز القبول من العلماء، ويكون هذا وفق معايير علمية لضبط وله التجديد في تفسير القرآن الكربم وعلوم القرآن. 


\section{الفصل الثاني}

\section{رؤي بعض العلماء المجددين في الإسلام \\ 1 - رئية الإمام الغزالي في تعديد الخطاب الديني}

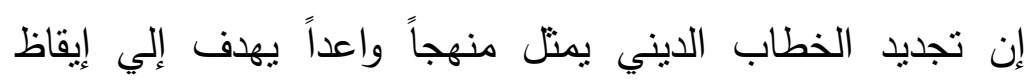
الضمير العام وشحذ إرادة الأمة ، واستتتهاض عزيمتها من كبوتها، واستتفار طموحتها وقواها المذخورة حتي تضع أقدامها علي طريق النهضة

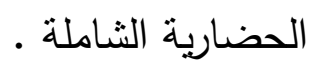
وأظن أن هذا الهدف هو الذي عمل له - ومن أجله - علماء المسلمين في شتي المجالات - وخاصة الدينية والتشريعية فوجدنا كل هل هون عالم مجتهد يأتي ويكمل ما قاله السابقون فيتمم البناء ويشيد بكل صفات الجمال.

ولذلك كانت دعوة المجددين للنصوص الدينية المقدة هي دعوة إلي قراءة جديدة لهذه النصوص وفهمها بروحها وغايتها لا بحروفها ومعانيها المباشرة، فالخطاب المتجدد هو الخطاب الذي نتبض خلاياه الحيوية في تفاعل خصب خصيب مع مشكلات الأمة وعتراتها وعقباتها (1) وهذا ما قال به العلماء السابقون - وأنا معهم - حيث أننا نجد بعض الأئمة المحققين من أمثال: حجة الإسلام أبي حامد الغزالي رحمه الله- الذي يقول في كتابه "إحياء علوم الدين"؛ التدبر في قراءته:

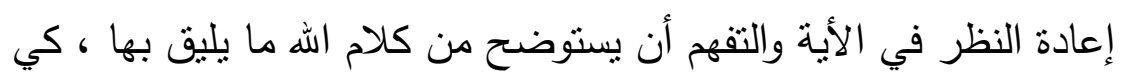

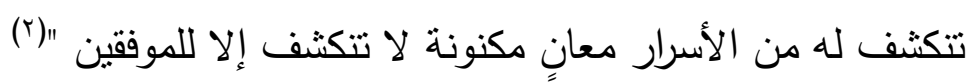
فما أجمل هذه الجملة التي نطق بها لإنها الغزالي في القرن الرابع

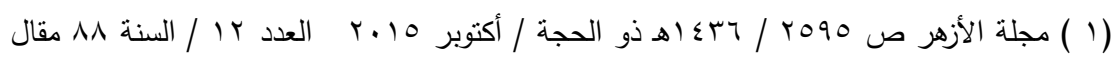

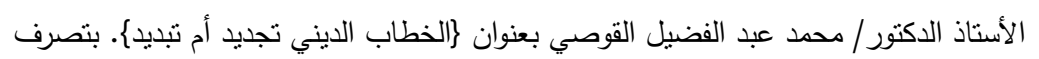

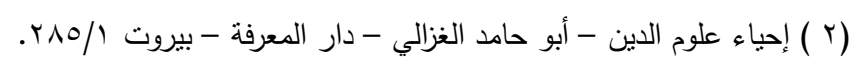


الهجري والتي ألمح فيها إلا أن عطاء الآية القرآنية ومحاولة التفهم - أي إجهاد المسلم نفسه لفهمها - لا ينقطع أبداً وإن الله يَمنٌُ علي المسلم الصادق النية فيفتح له أبواب من الأسرار لتلك المعاني المكنونة وهذا

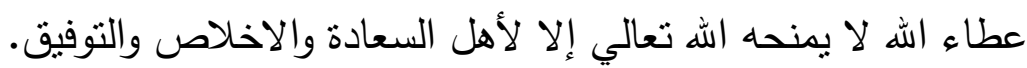
ثم يحدد لنا الامام الغزالي من خلال رؤيته لتجديد الخطاب الديني - أن هناك بعض الموانع التي تمنع فهم النص علي وجهه الصحيح فيقول - رحمه الهه - : ومن موانع الفهم أن يكون قد قرأ تفسيراً وأعتقد أن لا معني لكلمات القرآن إلا ما تتاوله النقل عن ابن عباس ومجاهدة أن وأن

ما وراء ذلك تقسير بالرأي فهذا من الحجب العظيمة. (1) كأنَّ الامام الغزالي ينظر إلي مستقبل الإسلام وتعامل بعض داءل المسلمين مع النص القرآني أو الخطاب الديني فيقصره علي فهم معين كتأويل ابن عباس وأقوال مجاهد في التفسير وهذا ما يمكن أن نسميه "بالنظرة السلفية" في التفسير ويحلو للبعض أن يسميه "التفسير بالمأثور وهذا ليس فيه عضاضة، ولكنه لا يمنع أن يكون بعض الاجتهادات والفيوضات التي يَمَّنَ الله تعالي بها علي من يثناء من عباده حتي يستمر عطاء القرآن الكريم علي طول الزمان مما يجعل البعض يسميه التقسير بالرأي - ونسي أو تتاسي - أن هذا هو التجديد في التفسير وخاصة بعد القرون الثلاثة الفاضلة : وهذا ما جعل البعض يذهب إلي القول بغلق باب الاجتهاد في نهايات القرن الرابع الهجري وبدايات القرن الخامس الهجري وهذا عكس الحقيقة والواقع التاربخي للأمة الإسلامية وعلمائها الإجلاء. 


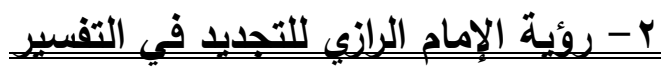

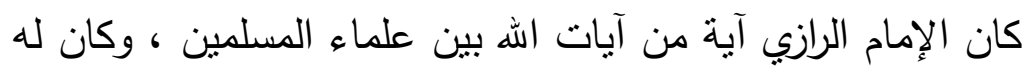

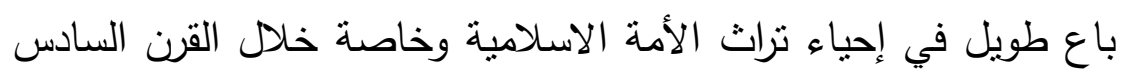

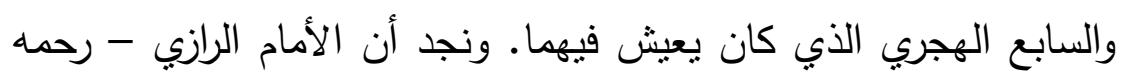

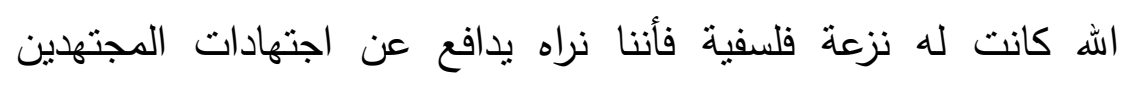

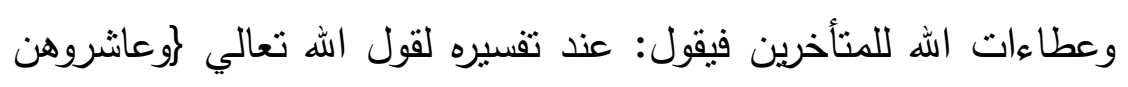
بالمعروف\{ النساء / 19 "وقد ثبت في أصول الفقه أن المتقدمين إذا أظهروا وجهاً في تفسير الآية فذلك لا يمنع المتأخرين من استخراج وجه أخر في تفسيره،

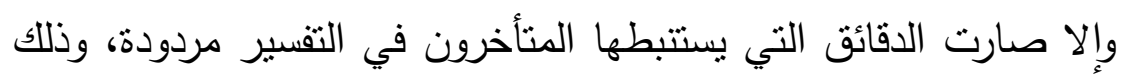

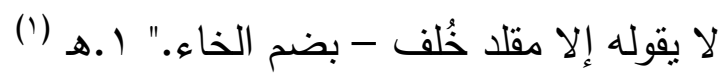

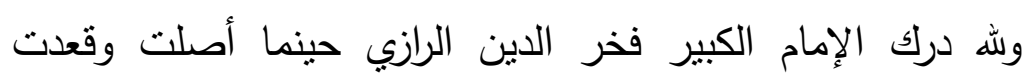

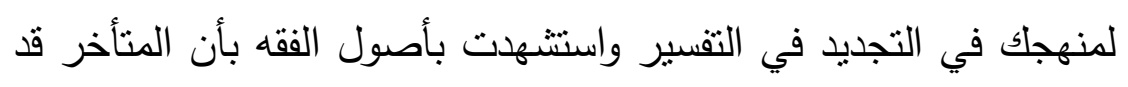

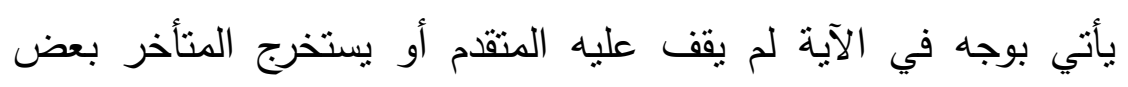

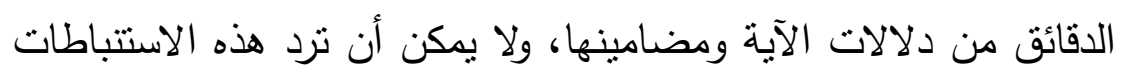

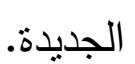

وإلا رددنا كثير من التفاسير المستجدة والمستحدثة بعد عصر القرون الثلاثة الفاضلة واكتفينا بما روي عن ابن عباس وبما جاء عن مجاهد وبما سطر عن أبي العالية وبما كتبه مسروق وبما انتهي إليه

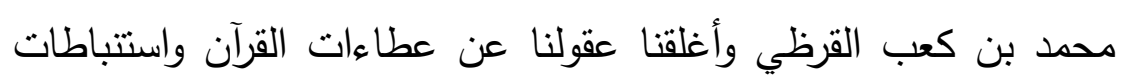

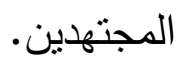

19/ (19) (19) (19) 
ويشن الامام الرازي حملة قوية علي من يعتقد هنا التوجه فيقول: وذلك لا يقوله إلا مقلد خُلف" وهذه اللمحة فيها الكثير فإذا كنا نشكك في إيمان المقلد ولا يكتفي بذلك فيتهمه بالخرف وخلاف الأولي.

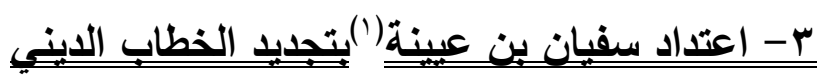
في أثناء كتابة هذا البحث - كنت أعرف - أن هذه القضية شائكة وتتاولها بعض العلماء وعلي حذر وخوف من اتهام بعض المتمسكين بالنص لهم بأنهم يدفعون في كتاب الله ما ليس منه - وساورني هذا الثك والخوف - في بعض الأحيان ، ولكن حينما وقفت علي ما قاله "سفيان بن عيبنة" في قضية التجديد - التي نحن بصددها - علمت صحة ما ذهبت إليه.

فيقول "سفيان بن عيينه - رحمه الله - في تقسيرة لقول الله تعالي

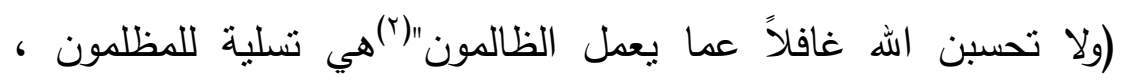
وتهديد للظالم، فقيل له: دن قال هذا ؟ فغضب، وقال: إنما قاله من علمه، يريد نفسه" لو نظرنا إلي ما قاله سفيان بن عيينة لوجدناه أتي بتفسير جديد،

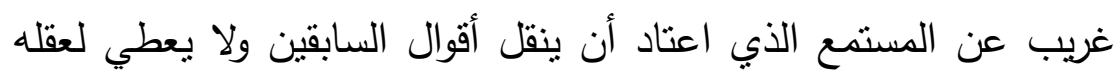
برهة للتفكير في نص القرآن الكريم، وقد استغرب هذا المستمع هذا

(1 ) سفيان عيينة الامام الكبير حافظ العصر شيخ الإسلام أبو محمد الهلالي الكوفي ولد سنة سبع

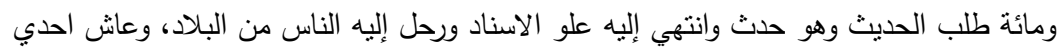

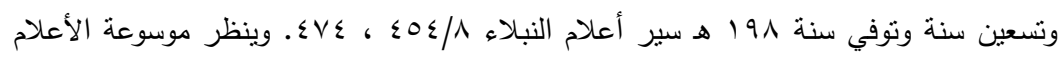

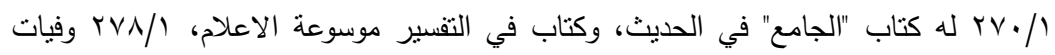

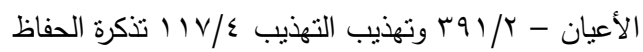


التفسير وذهب يسأل من أين جاء هذا التفسير؟ ليكون رد الفعل من سفيان.

هو الغضب علي من حبس عقله في تفسيرات السابقين، ويعلي سفيان بين عيينة من فهمه للنص القرآني فيقول: "قاله من علمه" أي من هن عرفه وفهمه ووقوف علي بعض المعاني الحقيقية في الآية ، ويعتز بنفسه وبفهه الذي هداه الله تعالي إليه من خلال تبصره للآيات القرآنية. وياليت هذا النهج سار في الأمة الاسلامية عبر تاريخها العام لكنَّا قد وجدنا حالاً للأمة غير هذا الحال الذي تعيشه. ولكن لعنة الله علي الجمود والجامدين الذين يعطلون حركة النماء والازدهار في الخطاب الديني عبر تاربخ الأمة الاسلامية.

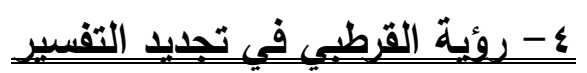

لو نظرنا إلي منهج الامام القرطبي في تفسيره المسمي "الجامع لاحكام القرآن والمبين لما تضمنه من السنة وأي القرآن" لوجدناه يضع منهاجاً وطريقاً للتجديد يبعد به عن السابقين ويحدد به واله الهذف من التفسير فيقول- رحمه الله: وشرطي في هذا الكتاب إضافة الأقوال إلي قائليها، والأحاديث إلي مصنفيها، فإنه يقال: من بركة العلم أن يضاف القول إلي قائله، وكثيراً ما يجيء الحديث في كتب الفقه والتقسير مبهماً، لا يعرف من أخرجه إلا من

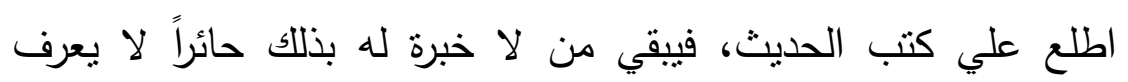

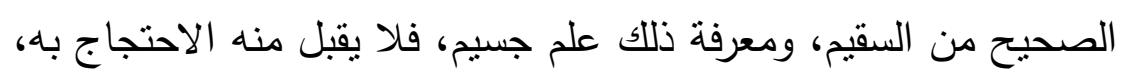
ولا الإستدلال حتي يضيفه إلي من خرجه من الإئمة الأعلام، والثقات

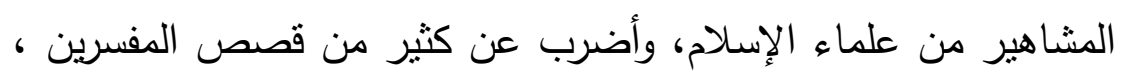
وأخبار المؤرخين ، إلا ما لابد منه ولاغناء عنه للتبيين، واعتفت من ذلك الأكن 
تبيين أي الأحكام بمسائل تسفر عن معناها، وترشد الطالب إلي مقتضاها، فضمنت كل آية تتضمن حكما أو حكمين فما زاد، مسائل نبين فيها ما تحتوي عليه من أسباب النزول والتفسير والغربب والحكم، فإن لم تتضمن

حكماً ذكرت ما فيها من التفسير والتأويل ، هكذا إلي آخر الكتاب. (') استتباط الأحكام التشريعية من القرآن الكريم

\section{ودور التفسير فيها}

بعد هذا العرض لما سبق من قضايا ورؤية لبعض علماء الاسلام

$$
\text { ومفسري القرآن نطرح هذا السؤال. }
$$

هل استنباط الاحكام التثريعية في القرآن الكريم من قبيل التفسير؟ وللإجابة علي هذا نقول ويالله التوفيق:

نعم إن استتباط الاحكام التشريعية في القرآن الكريم في خلال القرون السابقة للاسلام ليست إلا من قبيل التقسير لآيات القرآن لم يسبق تفسيرها من قبل ذلك.

وكان هذا هو دور العلماء علي مر ناريخ الاسام الزاهر فأنشأت المدارس العلمية وظهرت المذاهب الفكرية وبزغت الحركات الاصلاحية التي نشأت دن خلال توجيهات القرآن واستخراجها العلماء من دلالات الآيات ومحتوي الألفاظ. وللاستـلال علي هذا نري الإمام الثافعي رضي الله عنه كما جاء عنه في كتاب (الرسالة) يقول: طلبت دليلاً علي حجية الإجماع به الهابه

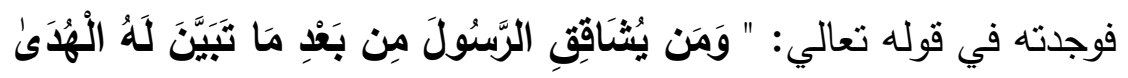

(1 ) تفسير القرطبي (الجامع لأحكام القرآن) /1/0 طبعة دار الغد العربي - الطبعة الثالثة 1919 ـ 


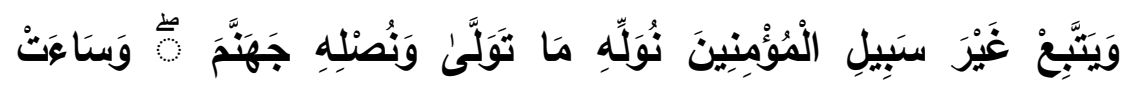

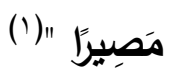

ونري عالماً من كبار علماء المسلمين يضع شرطا للتفسير الصحيح وهو الإمام شرف الدين الطيبي: فيقول: في شروحه علي لئي

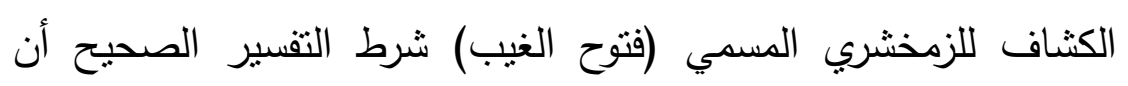

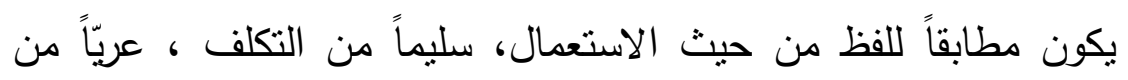
التعسف، فما كان علي خلاف ذلك فهو من بدع التفاصيل كما يسميه جار اله الزمخشري.

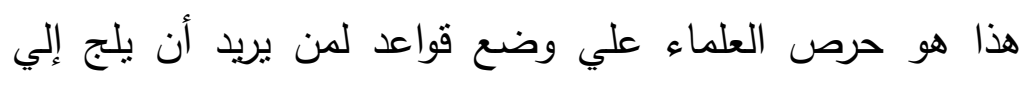
تفسير القرآن الكريم حسب المنهج الذي ارتضاه العلماء وسار عليه

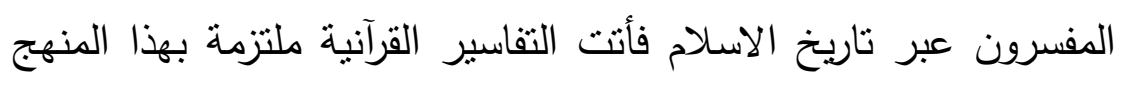

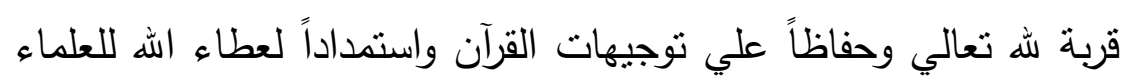
المخلصين.

ولذلك نري أن التفاسير قد اتسعت وتفنتت في أهدافها وغاياتها ومناهجها وزادت مستتبطات معاني القرآن بفضل ما رزق اله تعالي الذين أونوا العلم من فهم في كتاب الله تعالي".

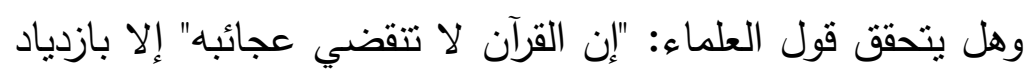

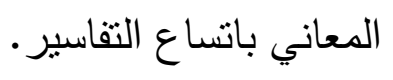
ولولا ذلك لكان تنسير القرآن مختصراً في ورقات قليلة، ولو وقف تفسير القرآن علي زمن معين وفهم معين. فماذا بعد ذلك؟ 
يعد ذلك وغيره نوعاً من التجديد الذي يتحقق به الهدف الأسمي من هدايات القرآن وإرشاداته.

وهذا هو الهدف من الخطاب الديني (المتجدد) فهو الخطاب الذي تتبض خلاياه بالحيوية في تفاعل خصب حصيف مع مشكلات الأمة وعتراتها وعقباتها ولن نجد أفضل علاج لكل هذه المشاكل إلا القرآن

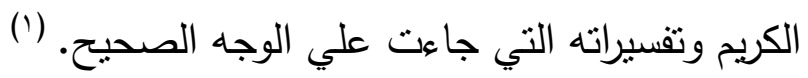
ولذلك كان التدبر وسيلتنا الدائمة - أي للمسلمين - لفهم القرآن الكربم والتدبر: هو التفكير فيما وراء الظواهر ، ومعرفة أدبار الأمور وعواقبها، فالقرآن خطاب مفتاحه التدبر : أي أن القارئ المؤهل الذي هيأ قوي وعيه ووسائل إدراكه لتدبر القرآن الكريم بعقل علمي لديه من المعرفة والاستعدادات ما يعينه علي تدبر هذا الخطاب، ومعرفة المراد منه. فالمتدبر: قد تلقي خطاباً في قول ثقيل متحد معجز ذي مواصفات لا يشاركه فيها أي خطاب آخر ، وله مضمون ورسالة وهدف ومقاصد وغايات وعواقب وهو خطاب

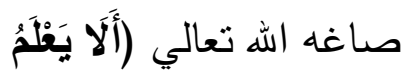

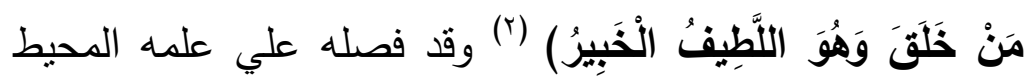
بكل شيء ، فهو علم مطلق

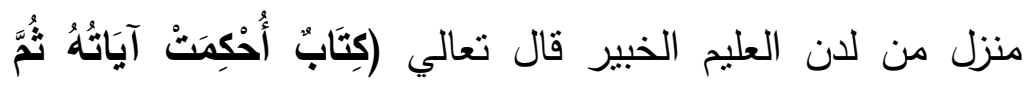

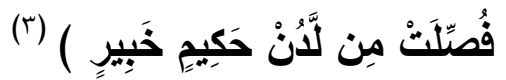
ولعل أهم الاختلافات بين ما بثيره الخطاب القرآني وأي خطاب

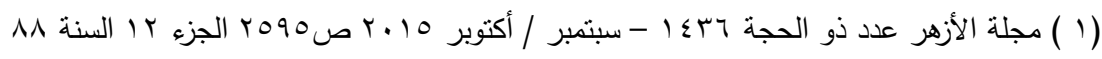
ا

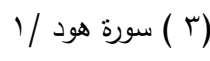


آخر غير الخطاب القرآني هو أنه يثير نساؤلات حول ما في ذهن مرسل

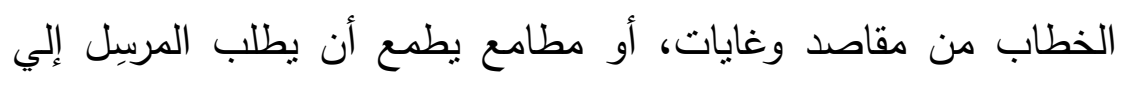

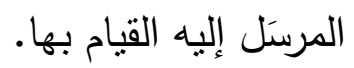
وهنا كان الرسول صلي اله عليه مثالاً واقعياً لخطابات القرآن ومنطلبات الوحي الإلهي ولذا عندما سئلت السيدة عائشة رضي الله عنها

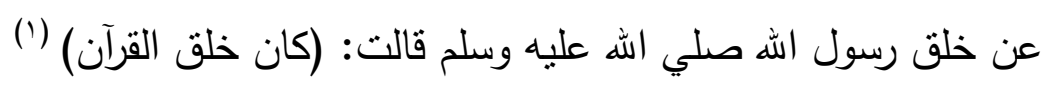
وعندئذ نكون مجموعة العلاقات الإنسانية والاجتماعية المتغيرة

المتحركة في إطار (المرجعية القرآنية وقيمها الحاكمة)

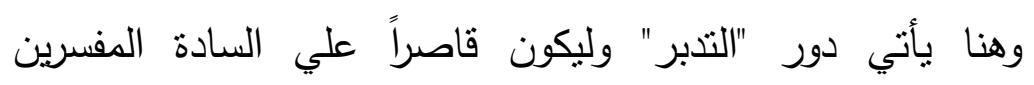

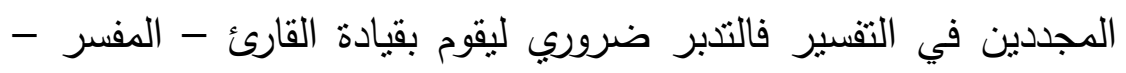
للتناعل مع الخطاب القرآني ومعرفة دوره بالنسبة إليه. وهنا يجد القارئ - المفسر - نفسه وجها لوجه في مواجهة الخطاب

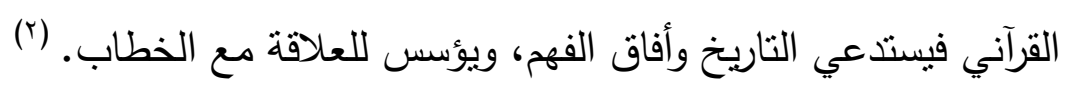
واعتقد أن هذا هو المطلوب في زمننا الحالي من أجل تجديد

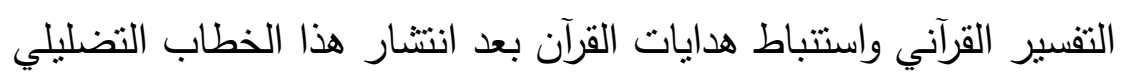

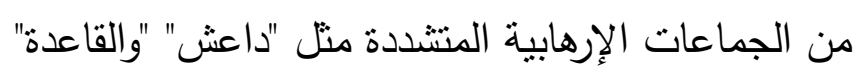
وغيرها من المذاهب الفكرية الوجودية والإحادية واللادينية.

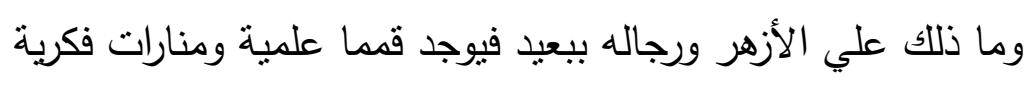

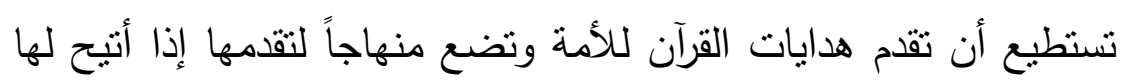

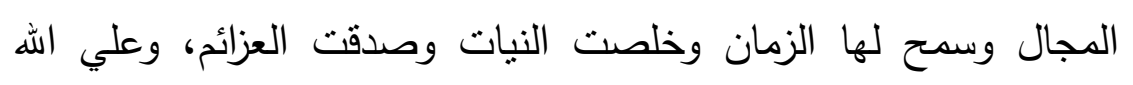

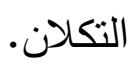

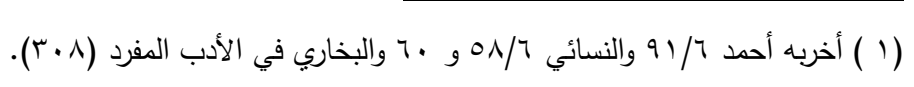

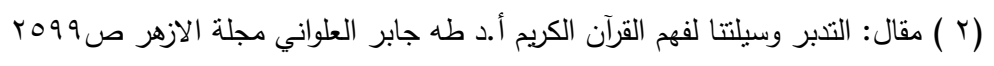


المسيرة التجدية للخطاب الديني عبر تاريخ الاسلام

إن باب الاجتهاد والتجديد مفتوح لكل من كان أهلا لهذا ، جامعا لهاعي

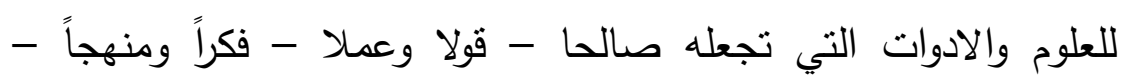
للاجتهاد والاستتباط وإلي هذا يشير القاضي البيضاوي بقوله: "لا يليق لتعاطيه - أي لتفسير القرآن - والتصدي للتكلم فيه إلا من برع في العلوم الدينية كلها أصولها وفروعها، وفي الصناعات العربية والفنون الأدبية. نعم لقد وضع الامام البيضاوي - وجهة نظره - لمن يريد أن أن وهنيه

يتصدي لتفسير القرآن كي يضبط الإطار الذي ينبغي أن يسير فيه المفسر ويكون علي هدي وبصيرة. ونري هذه المسيرة التجدية تمثل في كل مدرسة من مدارس التفسير العلمية كمدرسة مكة المكرمة ومدرسة المدينة المنورة ومدرسة الكوفة. فلكل مدرسة منهجها وطريقتها وعلمائها وشيوخها والتزامها بجانب من جوانب التفسير فنري ابن عباس في مكة المكرمة بشتغل بتفسير آيات العبادات كالصلاة والصوم والحج وغير ذلك وتهتم مدرسة المدينة بإبراز

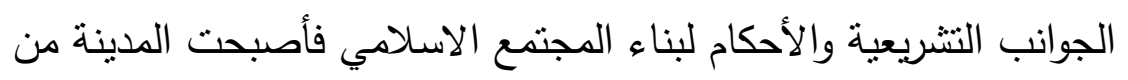
أكثر المدارس اثتغالاً بالمغازي والسير والسنن والأثار (') وجاء عصر التابعين فازدادت الحاجة إلي التقسير وبزيادة الفتوحات الاسلامية في بلاد الفرس والروم ومصر وغيرها ظهرت طبقة جديدة من الداخلين في الإسلام من هذه البلاد الجديدة المفتوحة. ونشأت المناهج التفسيرية وتعدي أثز مدرسة مكة والئد المدينة التفسيرية

(1 ) أقوال محمد بن كعب القرظي (جمع دراسة وتوثيق) رسالة ماجستير للباحث/ محمد إبراهيم أحمد

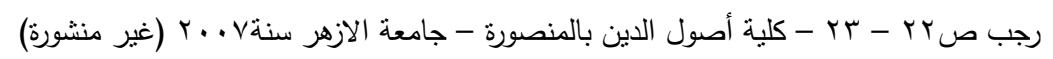


حتي وصل إلي بلاد اليمن فكان من أثنهر علمائها طاووس بن كيسان ووهب بن منبه ومعدر بن راثند البصري.

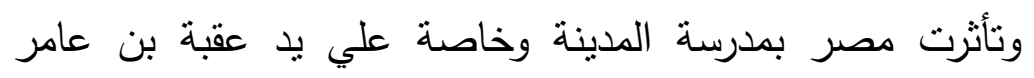

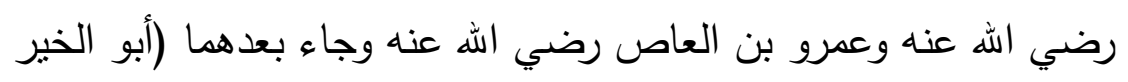
مرتد بن عبد الله المزني المنوفي سنة ،وصه حتي وصن العاصن رضي الأمر إلي الليث

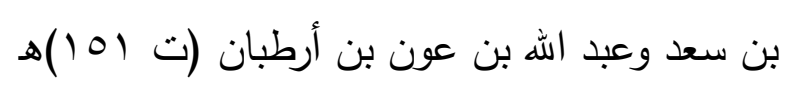
واستمر الحال حتي وصل إلي مصر كبار التابعين والعلماء كالإمام

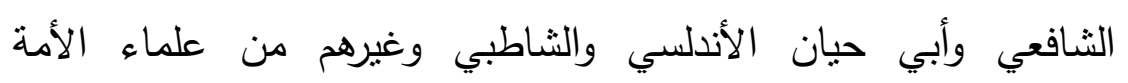
ومصابيح الهداية.

واستمرت مصر تحمل من خلال أزهرها الثريف ومنهاجه الوسطي التهاي

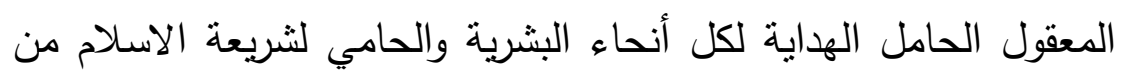

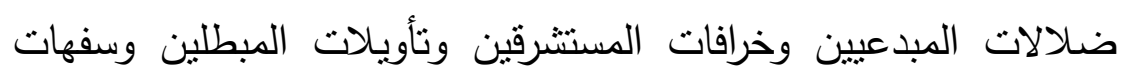

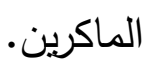

واستمرت المسيرة التجدية ناشرة فضلها علي الانسانية ومبصرة

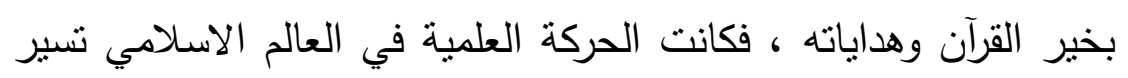

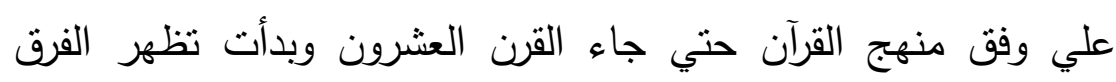

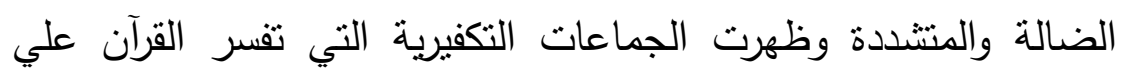
هواها وتأخذ القرآن إلي مبتغاها، وتوظف النص القرآني وتلوي عنقه إلي الي ما يحقق أهدافها وغاياتها حتي رأينا من وصل إلى إني تكفير المجتمع ورميه

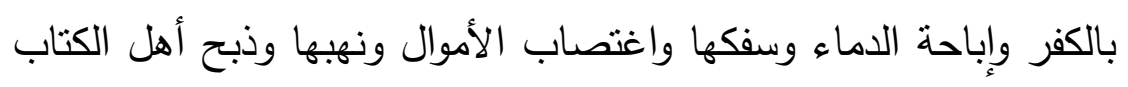

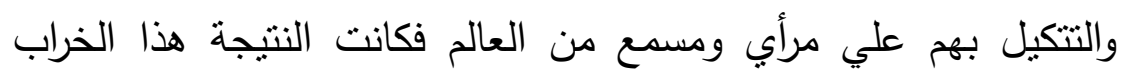

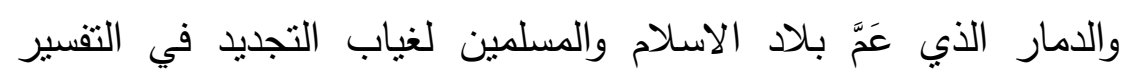
والتصدي لأفكار هذه الجماعات الضالة والمضلة. 
ونجد علماء الأمة المخلصين بسعون جاهدين للإلمام بمعاني القرآن

الكريم، وادراك مقاصده واستجلاء مراميه وغاياته، والوصول إلي برد اليقين في فهمه ومعرفة تقسيره وتأوبله كما جمعت سنة رسول الله صلي الله عليه وسلم وأثار الصحابة وفقهم وتقسيراتهم وتأويلاتهم، وفتاوي قرائهم لبلوغ تلك ويك الغايات، والعروج إلي سماء تللك الآيات ، فكانت حصيلة تلاك الجهود أن بلغت تراكمات ذلك حد بلوغ مرحلة تأسيس وتدوين العلوم ومنها

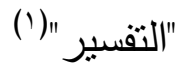

\section{التدرج التاريخي لقضية تجايد التفسير}

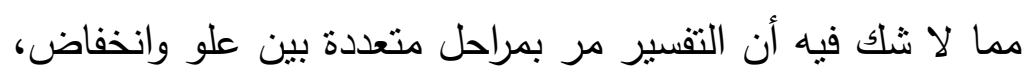
بين مد وجزر فكانت التفاسير الصحيحة وكانت التفاسير الفاسدة. فمنذ التفير النبوي للقرآن الكريم وقيام الرسول صلي اله عليه وسلم بتفسير بعض الآيات القرآنية للصحابة وخاصة عن طريق الأحاديث النبوية.

ومجئ القرآن ليفسر بعضه بعضا فما أُجمل في آية فسرته آية

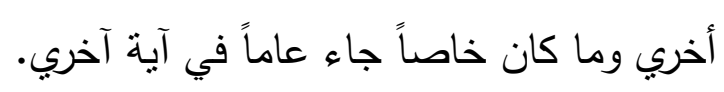

وحمل بعض الصحابة لواء التفسير وأثتهر به كابن عباس واس والخلفاء

$$
\text { الأربعة وعائشة وغيرهم. }
$$

ومجئ عصر التابعين وانتشار المدارس التفسيرية ودور كل مدرسة وعطائها التفسيري علي يد علماء أجلاء ومفسرين عظماء. وازدهار التفسير في عصر التذوين وظهور التقسير بالمأثور والتفسير بالرأي ودخول الإسرائيليات في التفسير ودور أقطاب الروايات

(1 ) أزمات الانسانية والحل القرآني د/ طه جابر العلواني صه،؛ هدية هيئة كبار العلماء - مجلة

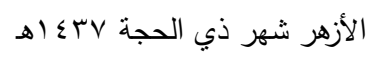


الاسرائيلية وبراعة شيخ المفسرين "الإمام الطبري" وكتابه (جامع البيان)

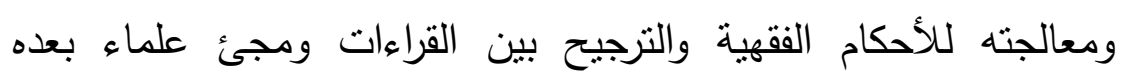

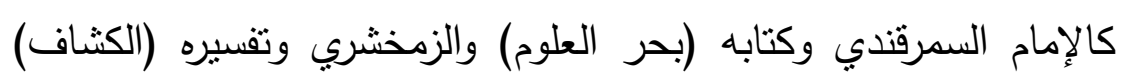

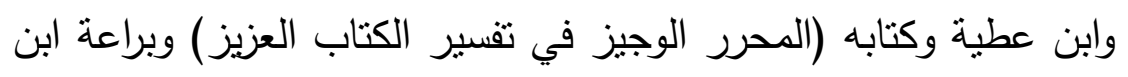
كثير في كتابه (تفسير القرآن العظيم) وبروز طريقته السلفية في التفسير فئريز وألمعية السيوطي في كتابه (الدور المنثور في التقسير بالمأنثر ) كل ذلك لا يخفي علي الدراس للتفسير.

ومجئ علماء التفسير بالرأي والاجتهاد وعلي رأسهم الإمام الرازي لافي لإني واهتمامه بالمناسبة بين الآيات والعلوم الرياضية والفلسفية وظهور البيضاوي بكتابه (أنوار التنزيل وأسرار النأويل)

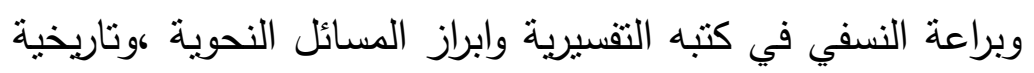
(الخازن) وعنايته بالأخبار التاريخية والناحية الفقهية. وظهور النجم الأوحد والعلامة الأعظم (أبي حيان الاندلسي) بكتابه الماتع(البحر المحيط) واهتمامه بالنواحي الاعرابية والقراءات القرآنية. حتي وصل الأمر إلي ظهور الخطيب الثربيني بكتابه (السراج المنير في الإعانة علي معرفة بعض معاني كلام ربنا (الحكيم الخبير)

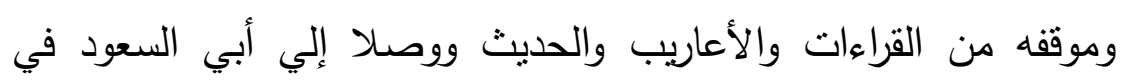

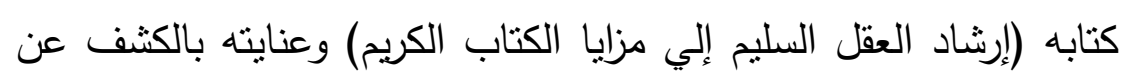
بلاغة القرآن وسر اعجازه وظهور علامة العراق محمود الألوسي بكتابه (روح المعاني في أليان

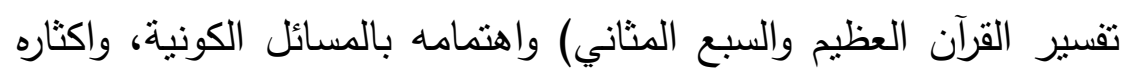

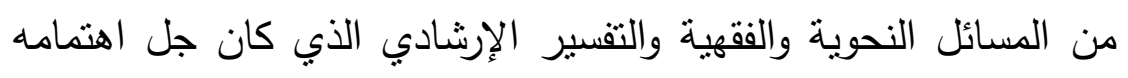

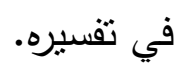


وظهور الفرق المبتدعة كالمعتزلة وأراءها ورد علماء أهل السنة عليها كابن قتيبة والإمام أبي الحسن الأشعري وابن تيمية وابن القيم وغيرهم من العلماء وظهور بعض تفاسير المعتزلة للقاضي عبد الجبار

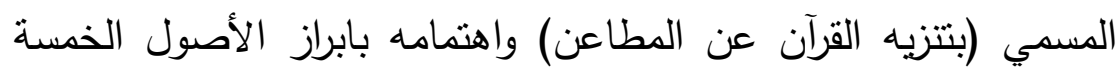
للمعتزلة. وظهور الزمخشري بكتابه (الكثاف عن حقائق التنزيل وعيون الأقاويل في وجوه التأويل) وقيمة هذا التفسير من الناحية اللغوية والاعجازية.

وحملة الزخشري علي أهل السنة ورد علماء أهل السنة عليه أمثال

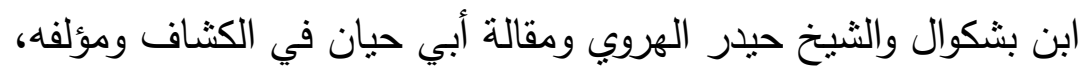
وهجوم ابن خلدون وتحرير الامام السبكي وحملة (ابن المُنَّير السكندري) علي الزمخشري، والصواعق المحروقة لابن القيم علي الزمخشري.

ولا ننسي هنا أن نذكر دور الثيعة وموقفهم من تفسير القرآن الكريم وخاصة (الامامية الاثتا عثرية) وحرصهم علي التوفيق بين ظاهر القرآن وباطنه وأثز التقسير الباطني في تلاعبهم بنصوص القرآن. وكانت لهم كتب سطروا فيها أراءهم وتصوراتهم منها علي سبيل المثال:

تفسير (مرآة الأنوار ومشكاة الأسرار) لعبد اللطيف الكازراني والحسن العسكري وتفسيره ورواياته المكذوبة علي أهل البيت. وتوسل الأنبياء والأمم السابقة بمحمد صلي الله عليه وسلم وبأهل البيت

$$
\text { وإبرازه مذهب (التقية) }
$$

وإلمام الطبرسي بمنهج الاثثا عشرية في كتابه رمجع البيان لعلوم القرآن\{ وتمسكه بعصمة الأئمة والرجعة والمهدي ونكاح المتعة ونكاح 
الكتابيات والغنائم وميراث الأنبياء.

ووقفا علي \}الملا محسن الكانشي\{ في كتابه \}الصافي في تفسير

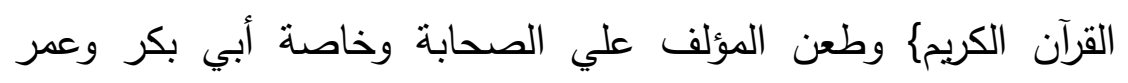

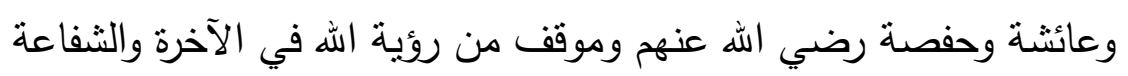
والسحر وروايته للأحاديثة الموضوعة.

وكان ظهور السيد/ عبد الله العلوي بكتابه (تفسير القرآن)

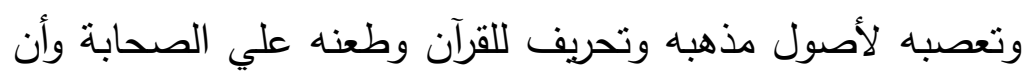

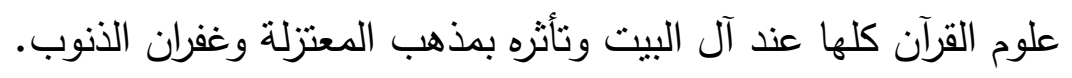

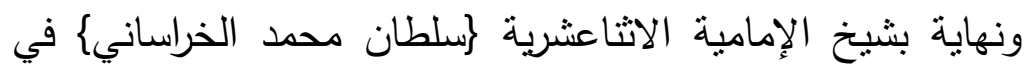

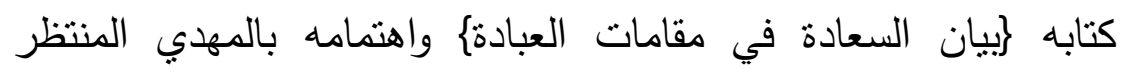

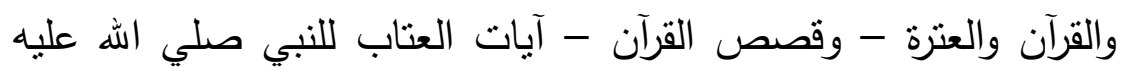
وسلم وفرض الرجلين في الوضوء وميراث الأنبياء.

وكانت الطامة الكبري ظهور الإمامية الإسماعيلية الباطنية\{.

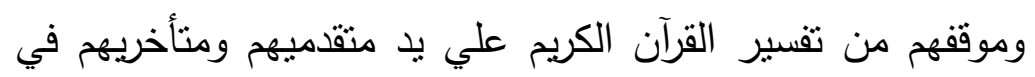

تقسير القرآن وانتشار مذهب الباطنية في البلاد وتعدد ألقابهم.

وكانت المصيية بظهور البابية والبهائية والصلة بين عقائد البابية

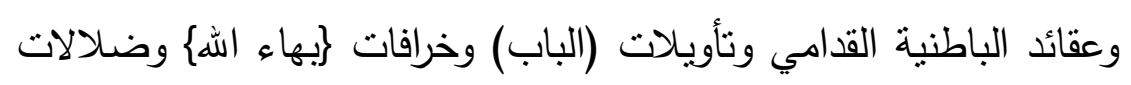

$$
\text { كبد البهاء عباس الباطنة }
$$

وبزوغ فجر الزيدية وعالمهم (الثوكاني) وكتابه (فتح القدير الجامع

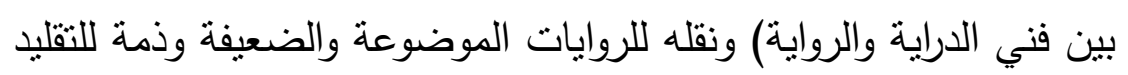

والمقلدين وموقفه من التوسل والمتثابه، ومسألة خلق القرآن.

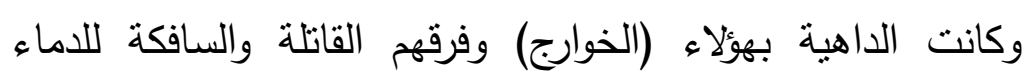

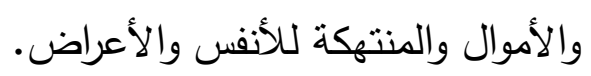

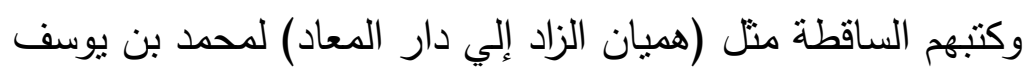


أطفيش وموقفه من أهل الكبائر، ومغفرة الذنوب ، وأفعال العباد، وإثادته بالخوارج وحطة من قدر عثمان وعلي ومن والاهما وحملته علي جمهور المسلمين.

وكانت هذه النظرة الصوفية:

وكان ظهور التفاسير الصوفية ومنها \}الفيضي أو الإثاري\{ ومقالة

الثاطبي وابن الصلاح وسعد الدين التفتا زاني وابن عطاء الله السكندري الانساي ومن أهم كتبهر \}حقائق التقسير\{ للسلمي و \}عرائس البيان في حقائق القرآن لأبي محمد الثيرازي و (التأويلات النجمية\{ لنجم الدين داية وعلاء الدين السمناني. والتفسير المنسوب لابن عربي. وتعصب تفسير الفلاسفة والتوفيق بين الدين والفلسفة والأثر الفلسفي

في التفسير كتفسير الفارابي وإخوان الصفا ومسلك ابن سينا في التفسير .

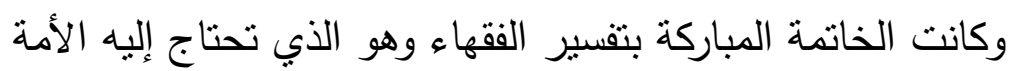
الإسلامية في بيان الأحكام فكان الإنتاج التفسيري للفقهاء مثل كأحكام القرآن\{ للجصاص الحنفي و \}أحكام القرآن\{ للكيا الهراسي الثافعي و أحكام القرآن\{ لابن العربي المالكي. \}والجامع لأحكام القرآن\{ لأبي عبد الله القرطبي المالكي كوكنز العرفان في فقه القرآن\{ لمقداد السيوري من الإمامية الاثثا عشرية.

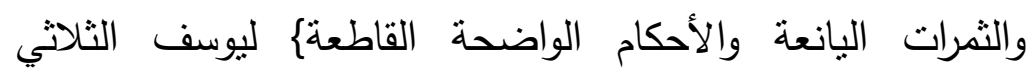
$\{\mid$ الزيدي)

وبزغ نجم التقسير العلمي واختلاف العلماء فيه بين القبول والرفض فكان من الداعين له الامام الغزالي والجله السيوطي وأبو الفضل المرسمي وظهور الرافضين لله وكان علي رأسهر الثاطبي رحمه الله.

ثم كانت ألوان التقسير في العصر الحديث وظهور التفسير العلمي بقوة نتيجة للاكتشافات العلمية والتجارب البحثية وتطور وسائل البحث 
العلمي وظهور دلالات الآيات وقربها من الاكتشافات العلمية مصدقاً

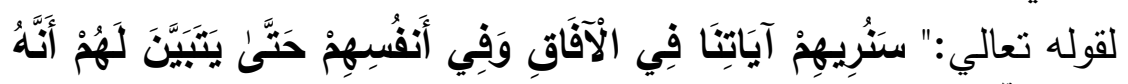

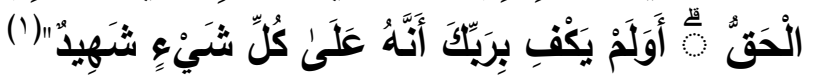

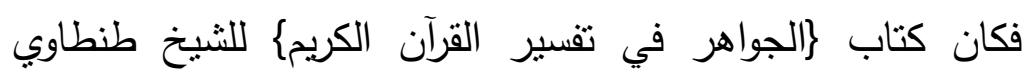

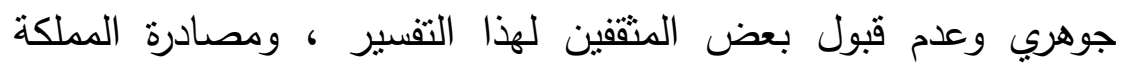

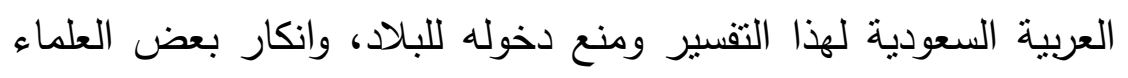

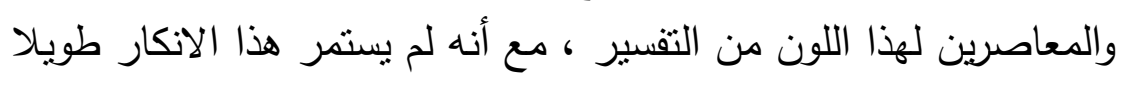

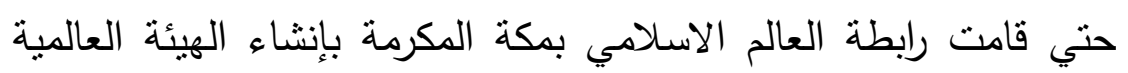

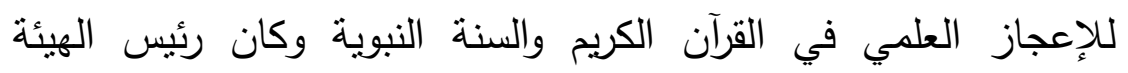

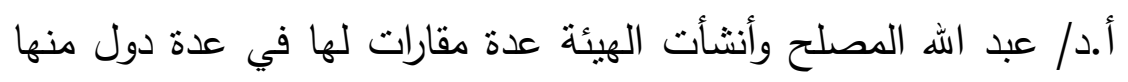

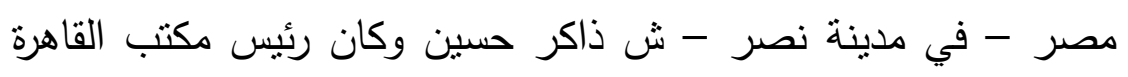
لمدة طويلة أ.د/ رفعت العوضي أستاذ الاقتصاد الاسلامي بجامعة الأزهر الثريف.

ظهور اللون الالحادي للتفسير في عصرنا الحديث:

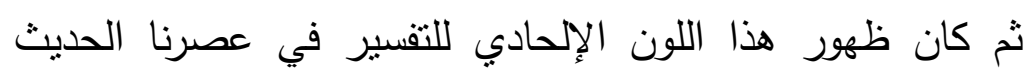

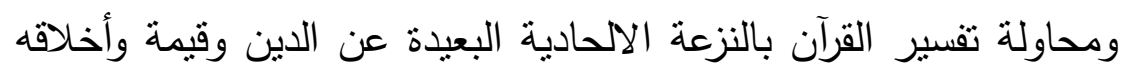

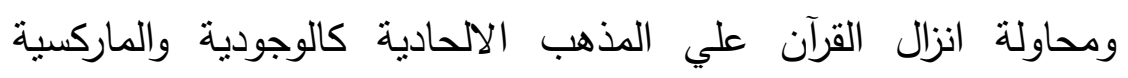

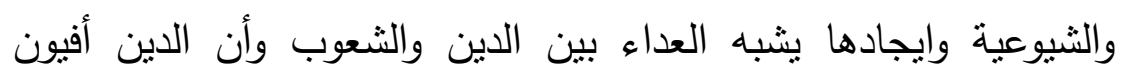

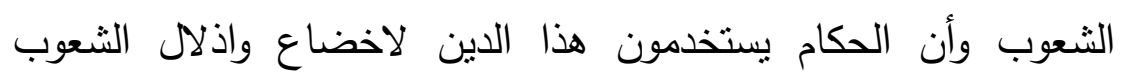
لتحقيق رغبات الحكام والرؤساء والملوك.

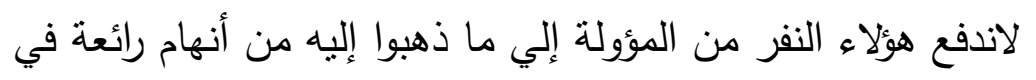
القرآن لعوامل مختلفة.

فمنهم من حسب أن التجديد ولو بتحريف كتاب اله هو سبب لظهوره وشهرته فأخذ يثور علي قدماء المفسرين ويرميهم جميعاً بالسفه

( ) ( سورة فصلت| 
والغفلة ثم طلع علي الناس بجديده في تفسير كتاب الله، جديد لا تقره لغة القرآن، ولا يقوم علي أصل من الدين.

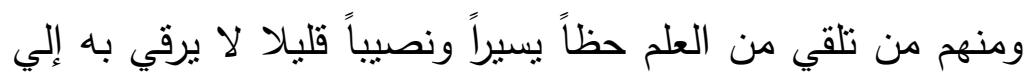

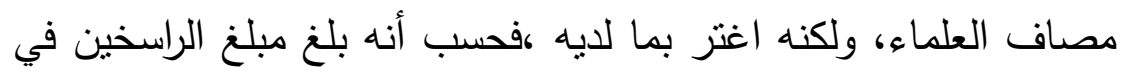

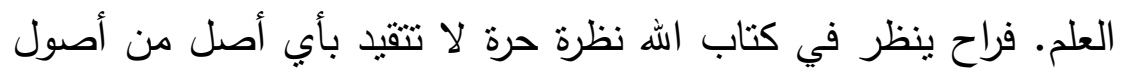
التفسير ، ثم أخذ يهذي بأفهام فاسدة، ثتنافي مع ما قرره أئمة اللغة وأئُة الدين (') وفهم من لم يرسهم لنفسه بحلة دينية، ولم يسر علي عقبدة

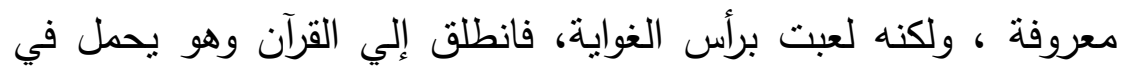
قلبه ورأس هذه الأمشاج من الأراء فأخذ يؤوله بما لا يتفق معها، تأوبلا لا يقرره العقل ولا يرضاه الدين. ولو أردنا أن نضرب أمثلة علي هذا اللون الالحادي لوجدنا الكثير

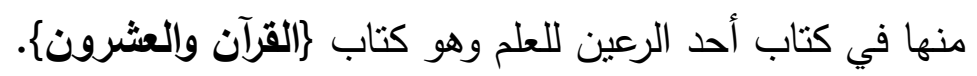

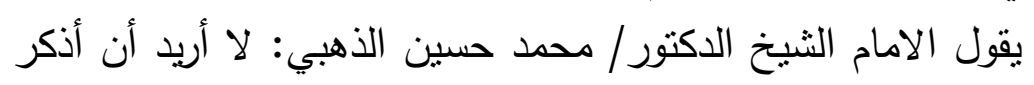

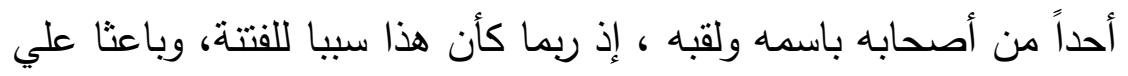

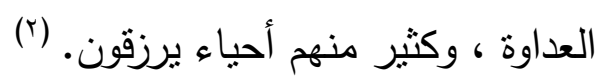

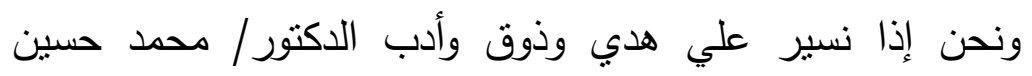

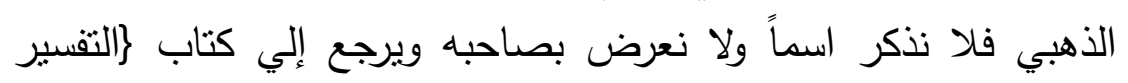

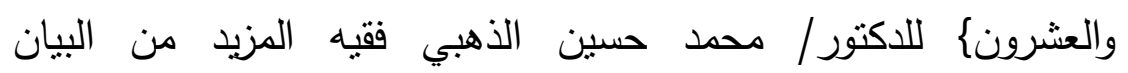

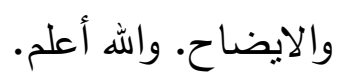

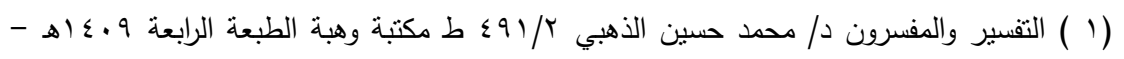




\section{اللون الأدبي الاجتماعي للتفسير}

\section{في عصرنا الحاضر}

يكاد أن يكون هذا اللون جديداً وطارئاً علي التفسير ويقوم علي

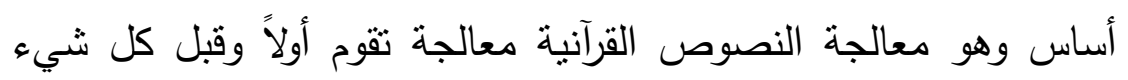

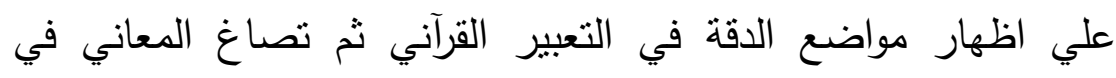

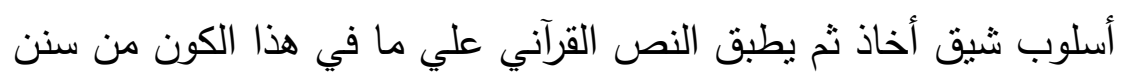
الاجتماع ونظم العمران. ويرجع الفضل في هذا اللون التفسيري إلي مدرسة الإمام الثشخ

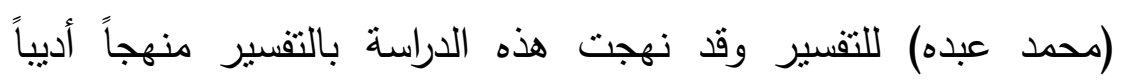

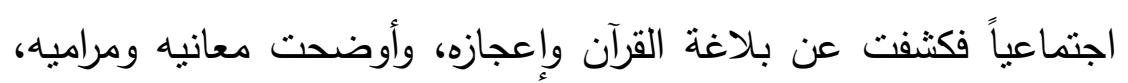

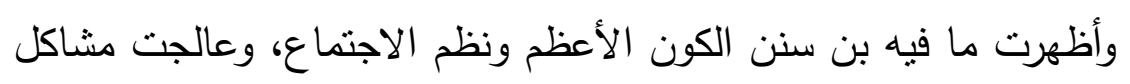

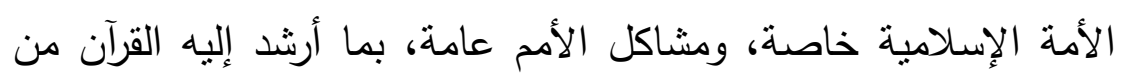

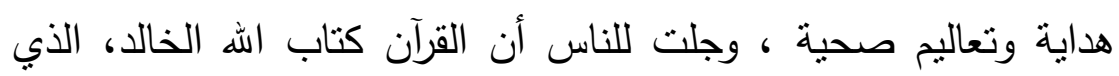

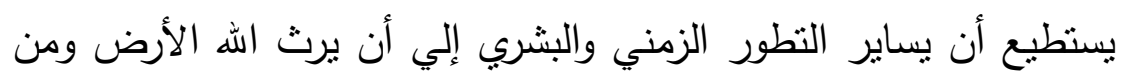

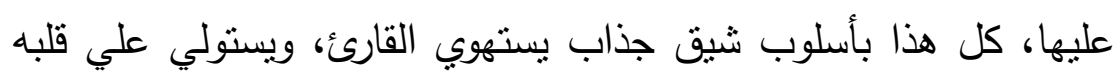
ويحبب إليه النظر في كتاب الله، ويرغبه في الوقوف علي بلي معاينة

وأسراره. (1)

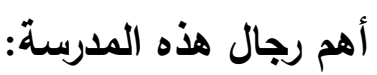

إن أهم رجال هذه المدرسة، هو الأستاذ الامام الثيخ/ محمد عبده

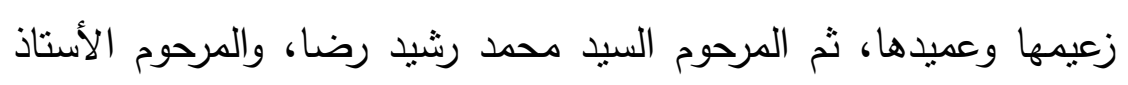


الأكبر الثيخ محمد مصطفي المراغي وهم خير من أنجبت هذه المدرسة، ثم يُيَّن الأستاذ/ محمد رشيد رضا هدفه من التفسير فيقول: إن حاجة الناس صارت شديدة إلي تفسير تتوجه العناية الأولي فيه إلي هداية القرآن علي الوجه الذي يتفق مع الآيات القرآنية الكريمة المنزلة في وصفه، وما أنزل لأجله من الانذار والتبشير ، والهداية، والاصلاحج(')

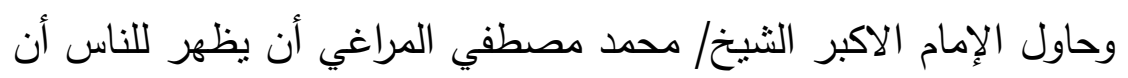
القرآن لا يقف في سبيل العلم، ولا يصادم ما صح من قواعده ونظرياته، وذللك بما يهديه الله تعالي إليه دن الدقة في التوفيق بين قضايا القرآن، وبين قضايا العلم الحديث(؟) وطلب الثيخ المراغي: أن يكون مفسر لئه كتاب الله علي شيء من العلم ببعض نظريات العلم الحديث ليستطيع أن يأخذ منها دليلاً علي قدرة الله، وبستلهم منها مكان العبرة والعظة)(ب)

كل هذه الألوان التفسيرية تعد من ألوان تجديد التفسير علي مر تاريخ الاسلام والمسلمين وجدناها تمر علي أيدي المفسرين المخلصين لكتاب الله البعيدين عن الشطط والجهل، ملتزمين باللغة العربية وأدابها وبلاغتها، متمسكين بتوجيهات القرآن واخلاق وتعليماته، مقتدين بآثار المفسرين السابقين عليهم ملتزمين بأصول التفسير التي اتفق عليها العلماء، وتمسك بها النابهين من المفسرين الذين مَنَّ الله تعالي عليهم بالعطاء، وألهمهم الحجة والبيان لتفسير كتاب الله علي هدي وبيان لتوصيله إلي عوام الناس

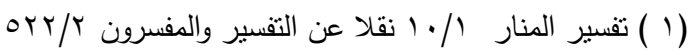

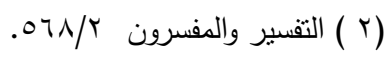

$$
\begin{aligned}
& \text { (r) (r) التقسير والمفسرون (r) }
\end{aligned}
$$


ولم يقف الأمر عند هؤلاء العلماء فجاءت الدكتورة/ عائشة عبد

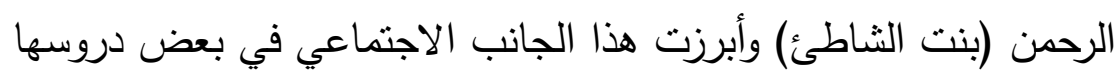
ومحاضراتها في جامعة القاهرة وزادت هذا الجانب إيضاحاً.

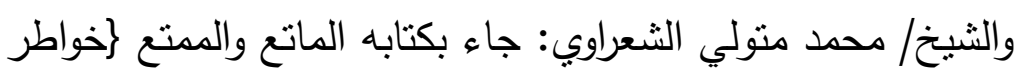

الثعراوي\{ وحاول ابراز الناحية البلاغية في القرآن الكريم وابراز مدي دئي

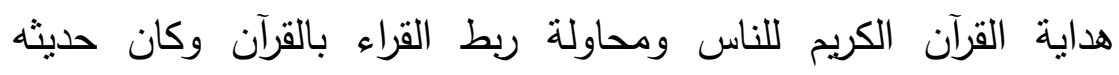

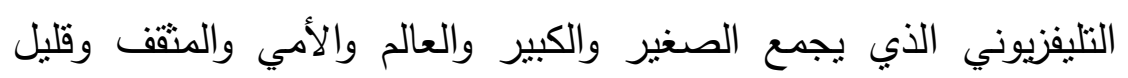
الثقافة الكل يأخذ من هذا التفسير الذي حاز القبول والثهرة ثم طبع في ولئي طبعة ورقية صارت بين يدي الناس. 


\section{ما هو الاستشرلق؟}

الاستشراق علي وزن استفعال ، كلمة تعني غالبا طلب شيء ما، فكأنه طلب "للثرق ، وقصد له كي يحصل عليه وعلي حضارته وعلومه وربما يكون بمعني الدخول في الثرق، فالمستشرق هو من يسافر إلي مشرق الثمس أو بلاد الثرق.

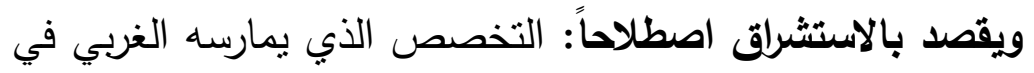
مجال دراسة الثرق علي مستوي لغاته وتاريخه ودياناته وثقاته وحضارته، انطلاقا من زوايا علمية متعددة.

ولا يختص الاستتراق بدراسة العالم العربي أو الاسلامي فقط بل

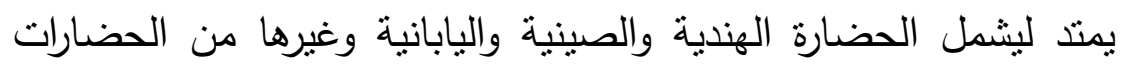
الشرقية الممتدة في بلاد المشرق.

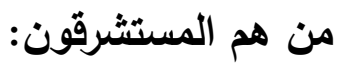

هم الوافدون إلي بلاد الثرق من دول الغرب في القرون الماضية

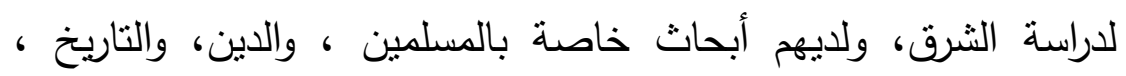
واللغة، والآثار وغير ذلك.

وقد ارتبط الاستشراق بالنتصير فكانت الدراسات الاستشراقية هي

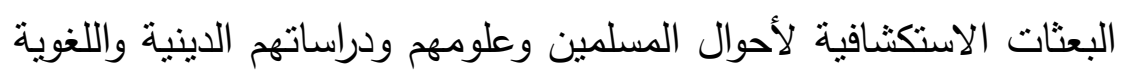
والأدبية والتاريخية

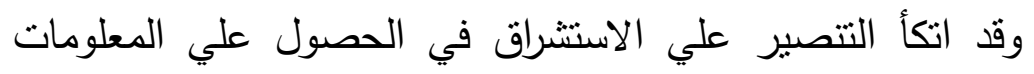
عن المجتمعات المستهدفة - ولا سيما - الإسلامية منها.

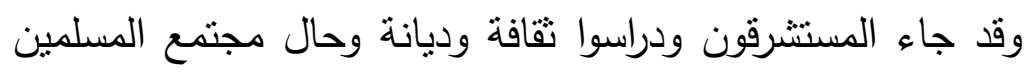

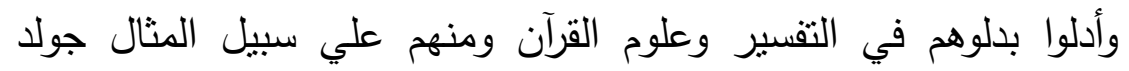
تسيمرالمتشرق المجري وكتابه (المذاهب الاسلامية في تفسير القرآن) 
ودائرة المعارف الاسلامية، وكتاب (المعجم الفهرس لالفاظ الحديث

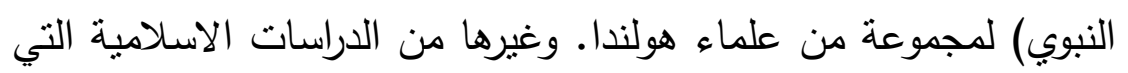

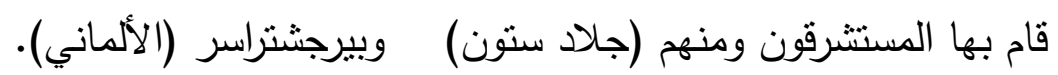

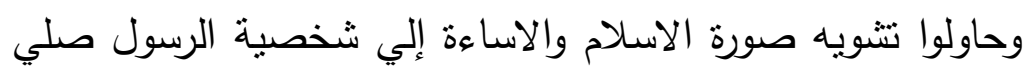

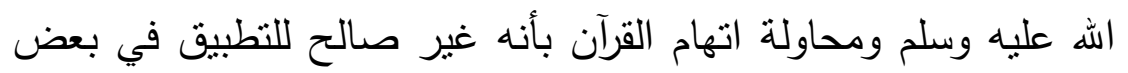
الأحكام وأنها تحتوي علي العنف والارهاب.

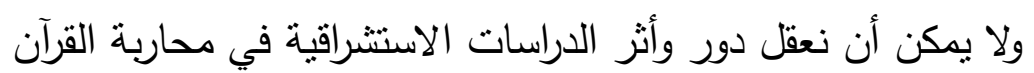

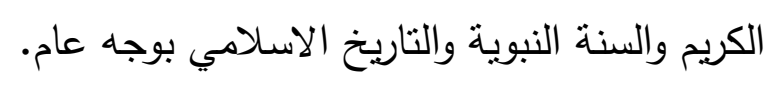

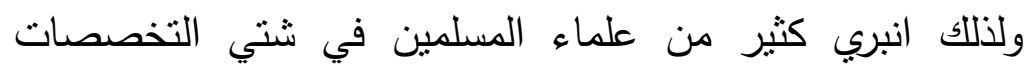

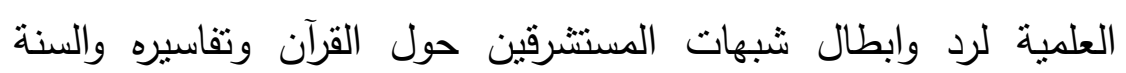

$$
\text { وعلومها والتاريخ الاسلامي وفضائله. }
$$

وذلك حينما قام بعض المستشرقين بعمل ترجمات للقرآن الكريم

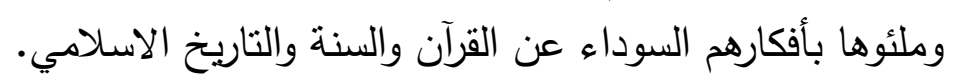

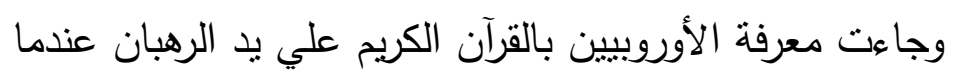

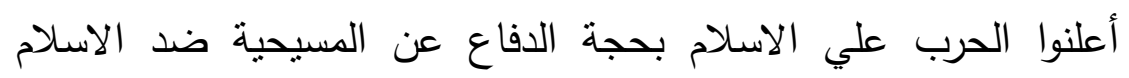

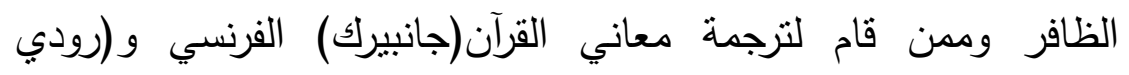

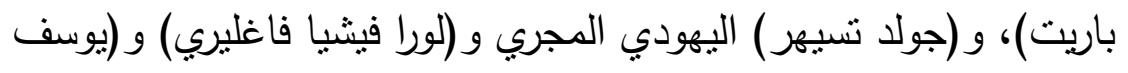

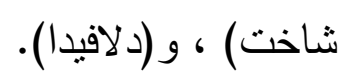

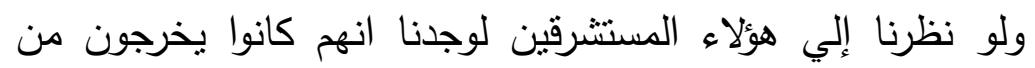

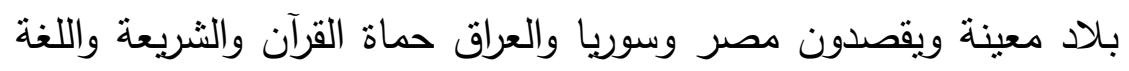

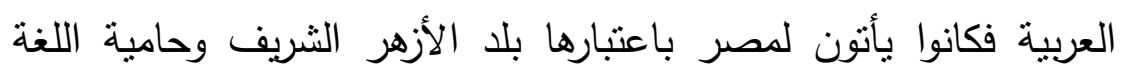

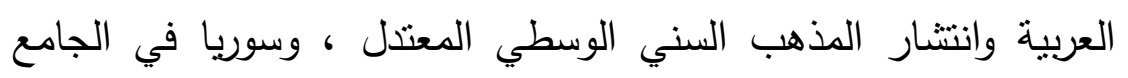

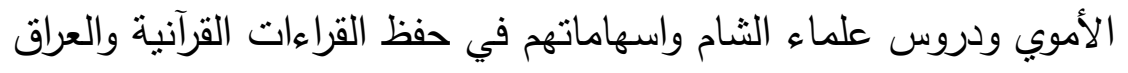
ومدارس البصرة والكوفة حيث وجود إرث اللغة العربية وتأصلها.

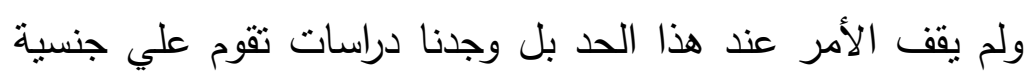




\section{قضية تجلديل الخطاب اللديني ( التجليد في مجال التفسيروالدراسات القرآنية )...}

هؤلاء المستشرقين فنجد دراسة بعنوان \}المستشرقون الناطقون بالانجليزية]

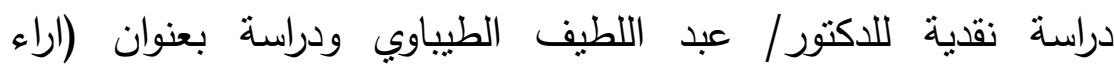

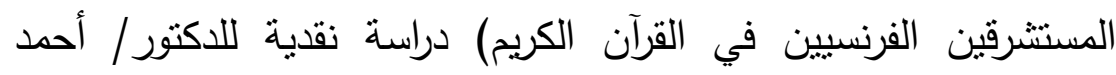

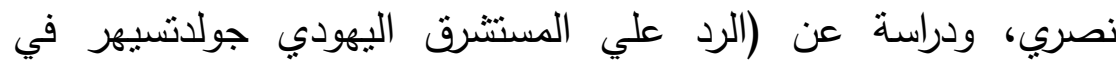

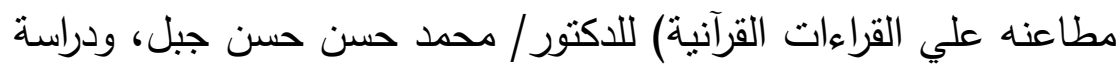

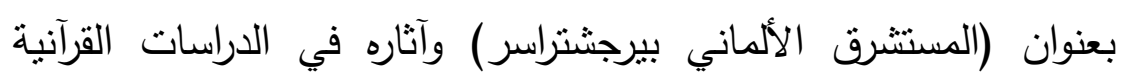

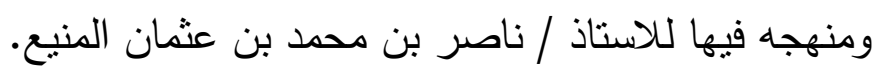

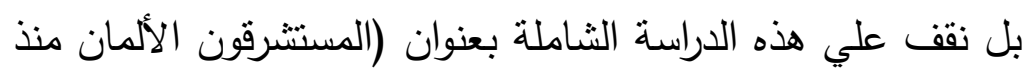

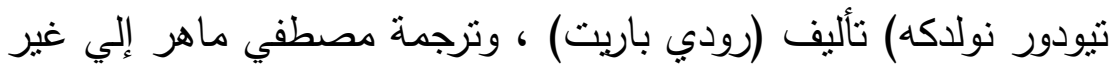

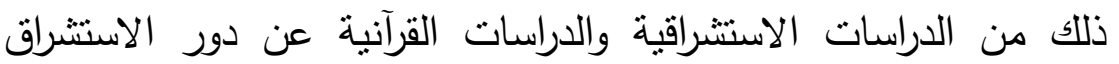

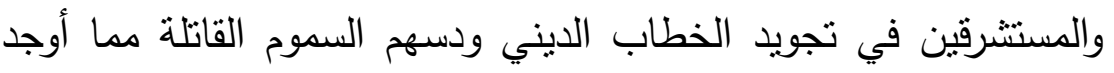
عند بعض العلماء المسلمين الغيورين علي دينهم وقرآنهم الحمية فانبروا

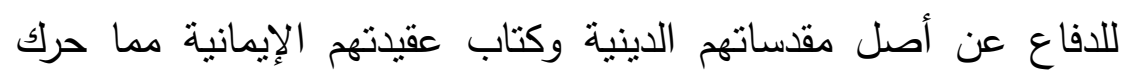
العقول والقلوب لصد هجمات المستشرقين علي تقسير كتاب الله نعالي وسنة نبية صلي اله عليه وسلم وتاريخ الإسلام الزاهر .

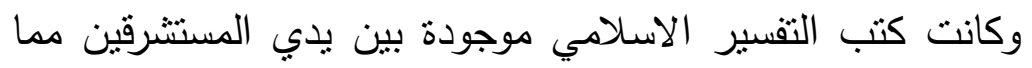

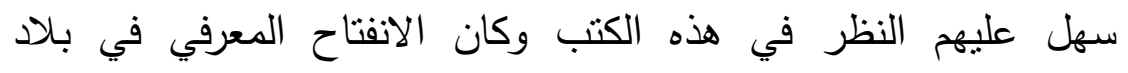

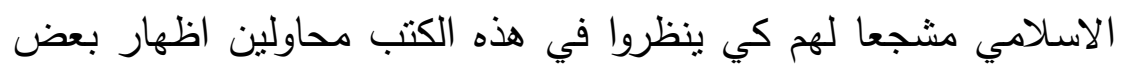

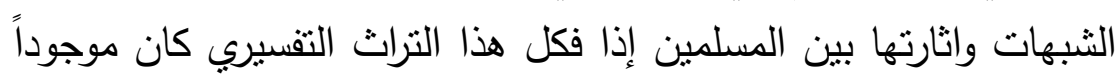

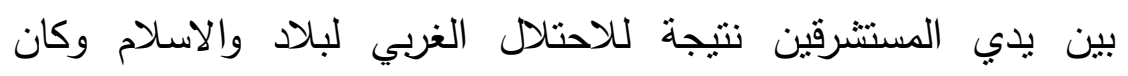

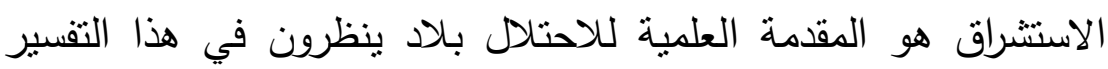

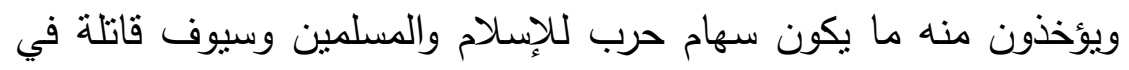

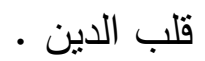
وترويج للأفكار الساقطة والتفاسير الباطلة لبعض علماء والمسلمين

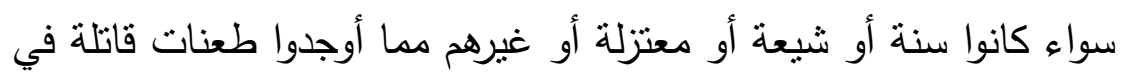


المسلمين وتشويه لصورة الإسلام في قلوب ونظر غبر المسلمين مما أوجد

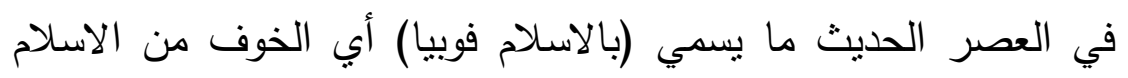

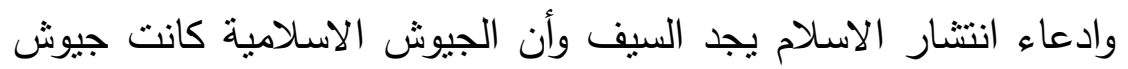

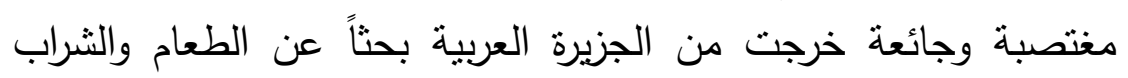
والحياة المريحة وليس جهاداً في سبيل الله لنشر الاسلام وتبليغ القرآن.

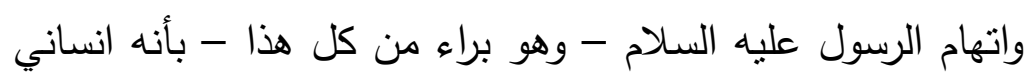

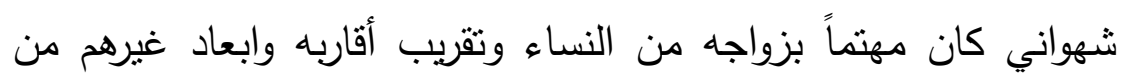
العطاءات إلي غير ذللك من الثبهات الباطلة والافتراءات الكاذبة دئة

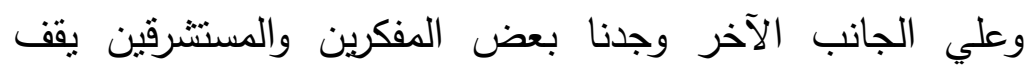

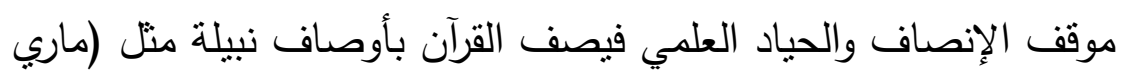

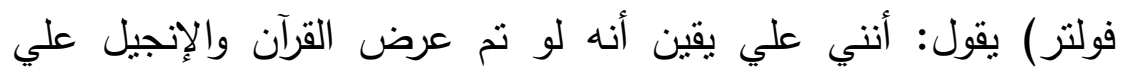

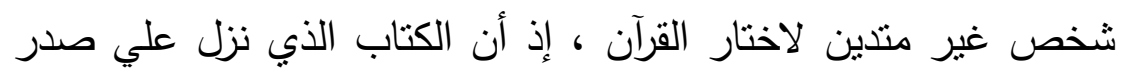

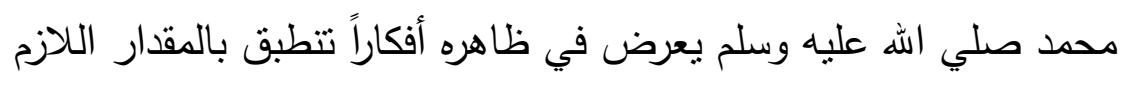

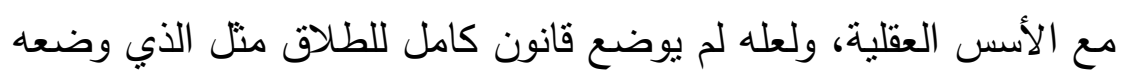

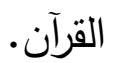

إذا فكل هذا التراث التفسيري كان موجوداً بين يدي المستشرقين

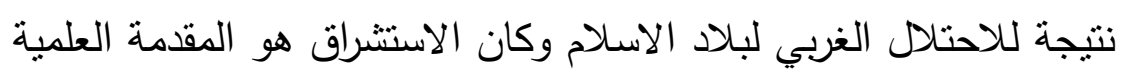

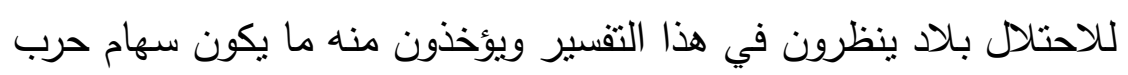

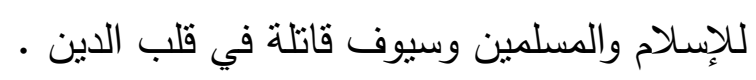

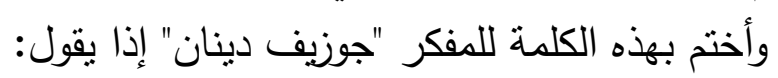

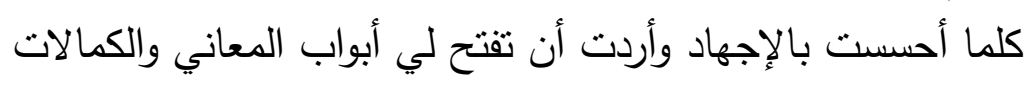

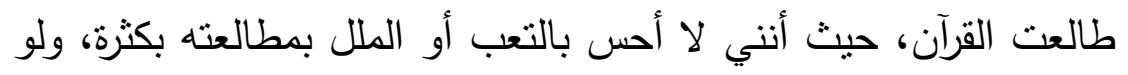

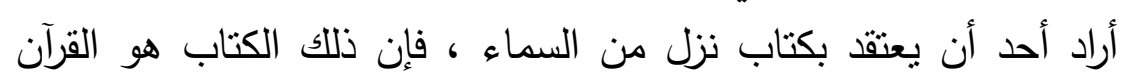

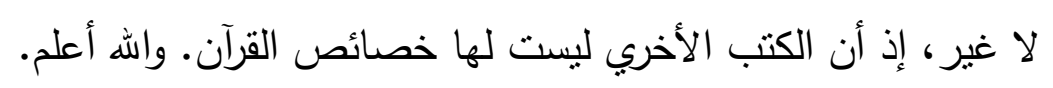




\section{الفصل الثالث}

\section{التحدبد في الدراسات القرآنبة ومنها علوم القرآن}

تتاولنا في الجزء الأول من هذا البحث التجديد في مجال التفسير واخترنا منهجاً وسطا يجمع بين القديم والحديث وبين الأصيل والمعاصرة ونريد أن نبرز الموضوع في ضوء الدراسات القرآنية ومنها علوم القرآن

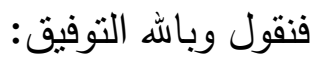

إن رؤيتتا للتجديد ليست بالجدة كل الجدة ولكن سبقنا إليها علماء قدامي ومعاصرون ونريد أن ندلو بدلونا في هذه القضية وهذا التجديد يتمثل في القراءة الجديدة للتراث واستحداث الوسائل والآليات واستخدم التكنولوجيا الحديثة لايصال العارف والمعلومات.

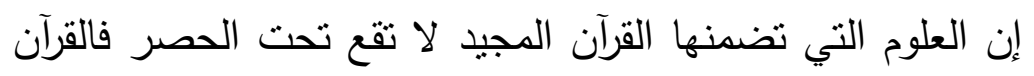
باطلاقيَّته ينكثف في كل زمان عن معارف وعلوم وسنن ونواميس وقوانين بحسب السقف المعرفي للبشر في ذلك الزمان حتي يستمر العطاء الإلهي للبشر من النص القرآني الكريم:

\section{التخصص الأول: علوم القرآن}

يتتاول هذا التخصص مفهوم الوحي وطبيعته والوحي المحمدي بصفة خاصة وأنواعه وكيفية نزول القرآن، والحكمة في نزوله منجماً، ثم جمعه وإعادة ترتيبه ثم يعرض لأهم العلوم التي تخصصت في في القرآن الكريم ومدارسها ومنهاهجها وبيان ما لها وما عليها ، وتدرس كذللك موضوعات التحدي القرآني والاعجاز وما عرف بغريب القرآن، ومفرداته ، ثم يعرض لأمثلة من بيان معاني القرآن بلغات غير عربية فيما يعرف

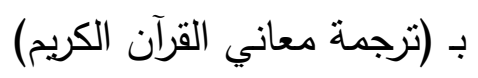
ثم يخلص التخصص إلي دراسة أثر البيئة والإنسان والثقافة في فهم

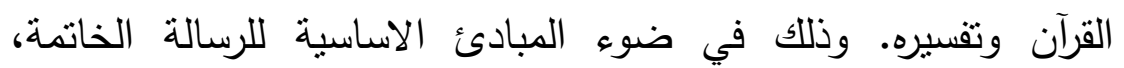


وعالميتها وخصائص الخطاب القرآني. ويشتمل هذا التخصص علي

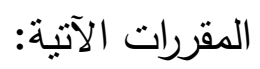

\section{المقرر الأول: في التعريف بالقرآن المجيد:}

يتتاول هذا المقرر موقع القرآن من (نظرية المعرفة الإسلامية) ويتتاول طبيعة خطاب القرآن، ويتتاول قراءة القرآن في ضوء سنن الكون وقراءة الكون في ضوء هداية القرآن، وايراث العلاقة بين سوره واجزائه وآياته ثم ينتهي إلي عرض أهم المحاولات المعاصرة لتطوير منهجية

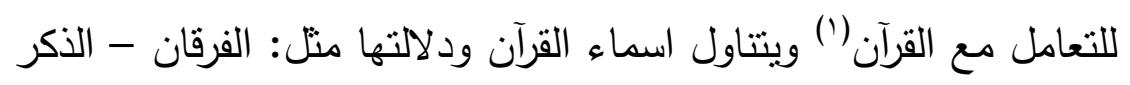
- الكتاب - التنزيل - النور - الهدي - الصراط المستقيم إلي آخره ويتتاول ما يمكن ابراز التحدي القرآني فيه أهو في التقرد البلاغي للبيان القرآني أو في صرف الناس عن محاكاته والاستجابة لتحديه سواء في عصر التنزيل أيام الرسول صلي الله عليه وسلم أو في خلاف الفرق

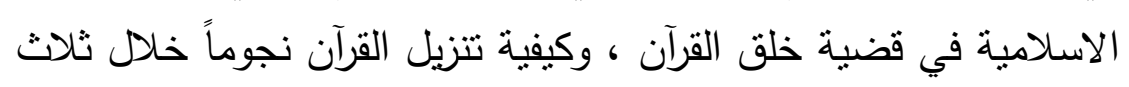
وعشرون عاماً.

ويتتاول أيضاً جمع القرآن وتدونيه ومتي سمي القرآن بالمصحف

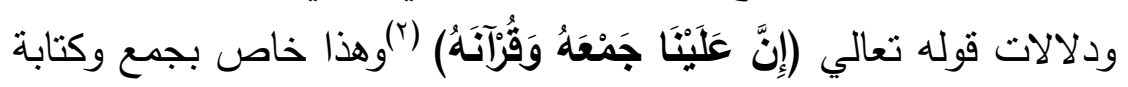
القرآن علي عهد رسول الهه صلي الله عليه وسلم. ثم الجمع الثامل بآمر - عثمان بن عفان رضي الله عنه - بنسخ وكتابة (المصحف الإمام) من صحف حفصة بنت عمر بن الخطاب مروراً بجمع أبي بكر الصديق وتجويد المصحف العثماني مما ليس بقرآن وتتابع الأجيال الاسلامية في تجويد المصاحف العثمانية وتحسين كتابتها

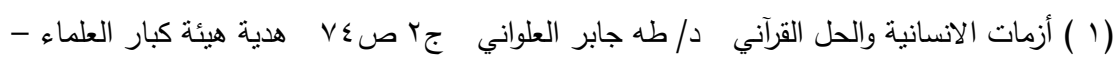

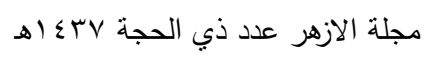

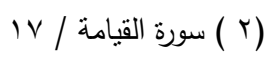


وبيان ما يتعلق بالتوقيف في ترتيب الآيات والسور واسماء السور

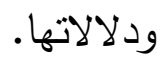

وتتاول قضية علم (الناسخ والمنسوخ) ماله وما عليه وكيف نشآت

أفكار النسخ حتي تحول إلي "نظرية ثابتة" في علوم القرآن وتأثزها ببعض وكان النظريات اليهودية والخلاف بين النسخ والبداء.

واظهار جانب البعد التاريخي في دراسات (الظاهرة القرآنية) وبيان أهمية علم (أسباب النزول والمناسبات) مروراً بقضية (الأحرف السبعة) وعلم (المحكم والمنتابه) وكل هذه القضايا تحتاج حلا حاسماً، وقولا نهائية فيها. المقرر الثاني: التفسير ومدارسه واتجاهاته:

هذا المقرر لله جانب هام من دراسة التجديد لعلوم القرآن إذ يشتمل

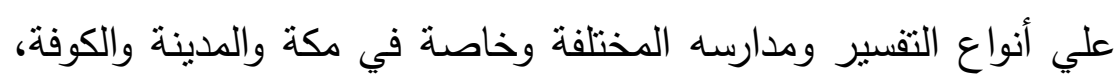
ويقدم نماذج من تفاسير تلاك المدارس وأصحابها وتلاميذها وذلك في إطار

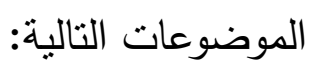

(1) مدرسة تقسير البيان بالبيان أو القرآن بالبيان - الاتجاه اللغوي منل

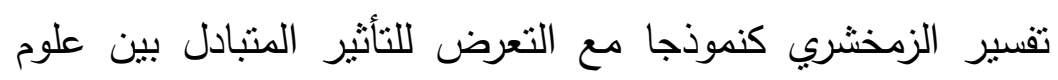
اللغة العربية وعلوم القرآن.

(Y) مدرسة تقسير القرآن بالمأثثر : المنحني النقلي - كالطبري وابن كثير والسيوطي في الدر المنثور ، ويقدم نماذج لذلك.

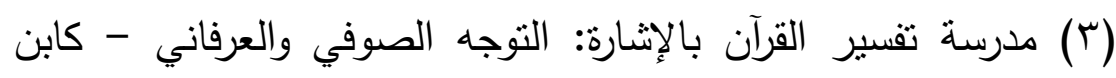
عجيبة في تقسيره، وابن عربي في تقسيره، والقشيري في لطائفه، والألوسي في تقسيره روح المعاني ويقدم نماذج لذلك.

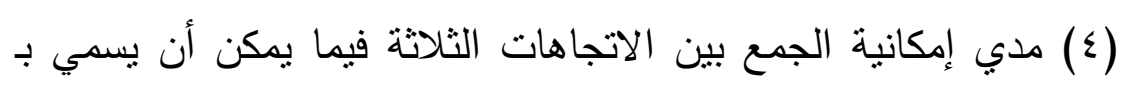
(منهج أواتجاه التفسير التكاملي) 
(0) عرض نماذج من التفاسير المعاصرة ومناقتنها: كتفسير المنار

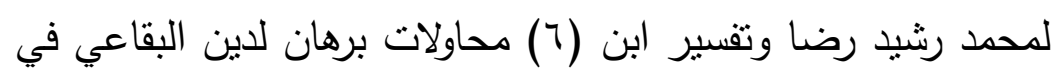

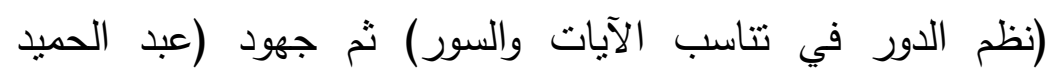

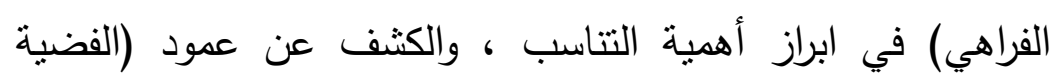

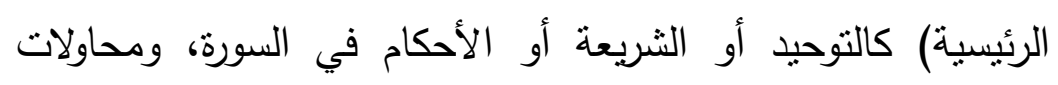

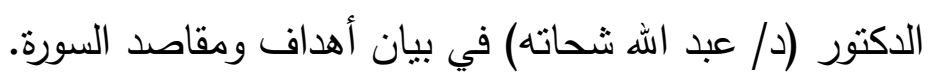

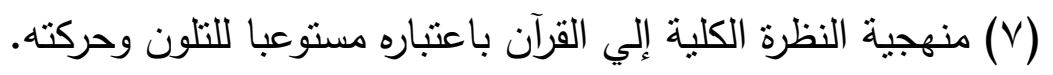

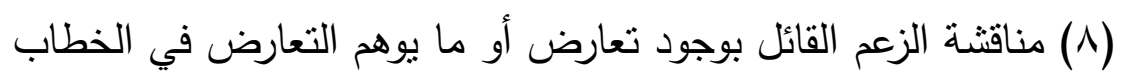

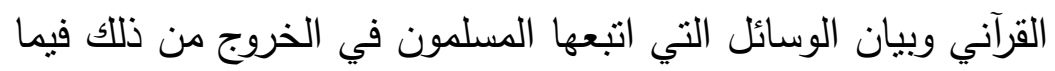

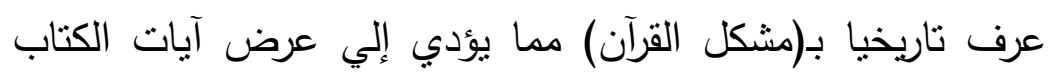

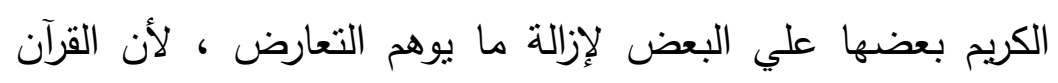

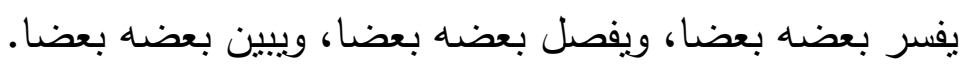

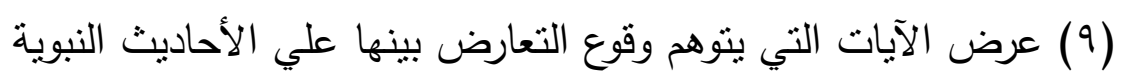

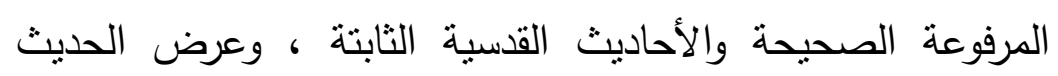

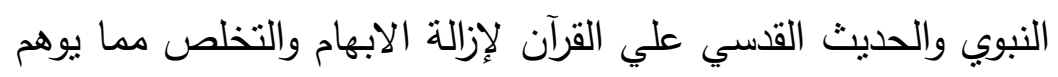
التعارض والتوكيد علي الصحة.

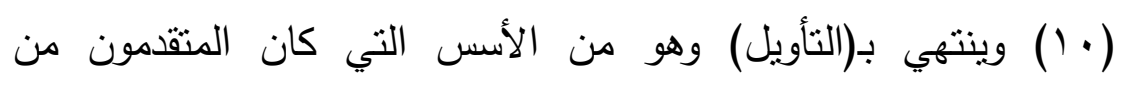

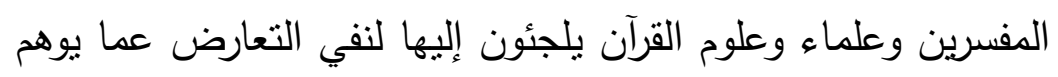
التعارض. أو أنه كثف للمحذوف الكامن وراء المثبت، لأن ما يثتبه لئه

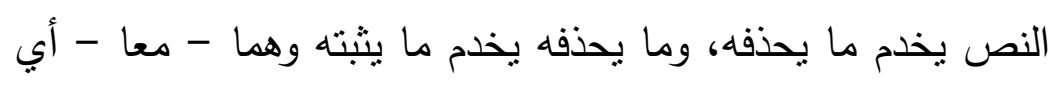
المثبت والمحذوف يتممان فكرة الحضور 


\section{المقر الثالث: القرآن والإيمان:}

هذا المقرر علي جانب عظيم من الأهمية إذ يمس جانباً مهما من جوانب الحياة الاسلامية.

$$
\text { فيتناول هذا المقرر: }
$$

(1) (الإيمان والعقيدة) كما يعرضها القرآن الكريم قبل أن تتعرض لإقامة عناصر كثيرة لأسباب مختلفة ، ويوضتح العلاقة بين القرآن وعلم الكلام، ويتتاول الظروف الفكرية والسياسية والاجتماعية لنشأة (علم النمان الكلام) ودوره الايجابي في بداياته في توضيح أركان (العقيدة الإسلاميةج ثم يتتاول تطور العلم وتحوله في إطار عقلية (تأزيم الحلول) إلي مفرق تنقسم عنده الأمة إلي فرق وشبع وأحزاب وجماعات تفائل بعضها بعضا. (r) ثم يتتاول نشأة أهم هذه الفرق الكلامية أو محاور الاختلاف بينها، بعاء والمؤثرات التي أدت إلي ذلك وما انتهت إلبه وذبولها، وجعلها سطراً في كتب التاريخ.

(ب) ثم يتتاول ضرورة هذا العلم في تحليل وتقويم مختلف العقائد الدينية. (ع) ثم يعرض لأهم قضايا علم الكلام سواء المتعلقة باله - سبحانه وتعالي - أو بأفعال العباد، أو بالمشيئة الإنسانية ، ونظرية التكليف، ومصادر تقييم الفعل الانساني ومعاييره، ليؤدي هذا المساق إلي تطوير "رؤية قرآنية معاصرة للعقيدة" وهذا مما بسهل علي مفسر القرآن والمتحدث عن علوم القرآن وتوصيله إلي الناس بلغة سهلة وبسيطة بما يتتاسب مع معطيات العصر الحديث وتطورات الحياة المتلاحقة. 
(0) تحويل علم الكلام إلي علم يجيب علي (الاسئلة الكلية) بو(الاثكاليات النهائية) للوجود الانساني في الكون - وتمبلمين

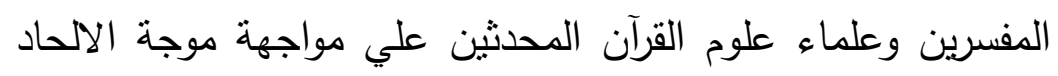

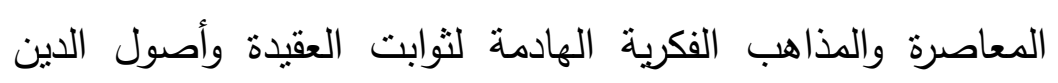
الحنيف المستمدة من القرآن الكريم والسنة النبوية الصحيحة.

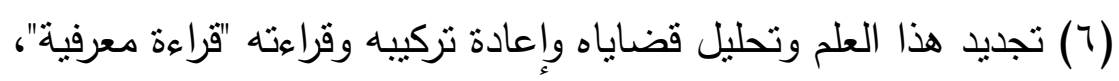

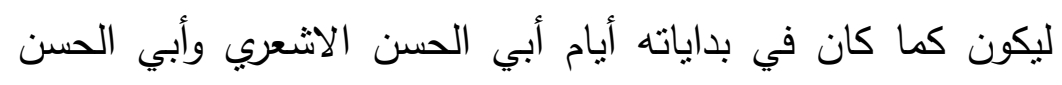

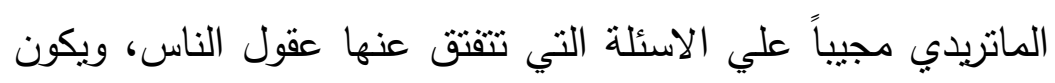

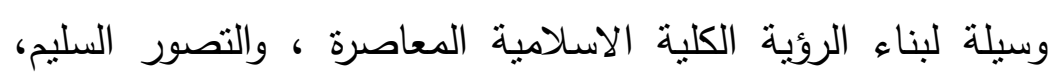

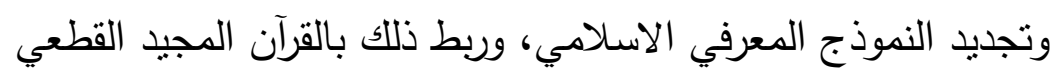
في ثبوته ودلالاته لئلا تخبو جذوة الايمان في قلوب الهابله أهله.

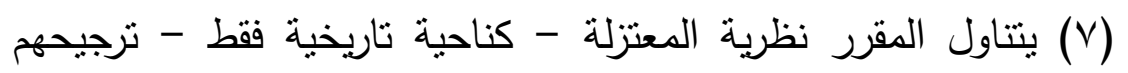

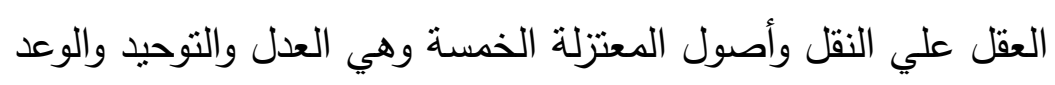
والوعيد والمنزلة بين المنزلتين والأمر بالمعروف والنهي عن المنكر .

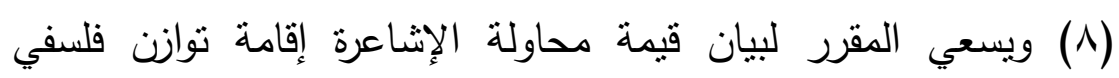
توفيقي للتوسط بين العقل والنقل باعنبار الوحي مصدراً للتكليف والعقل - هبة الله للانسان - مصدراً للمعرفة.

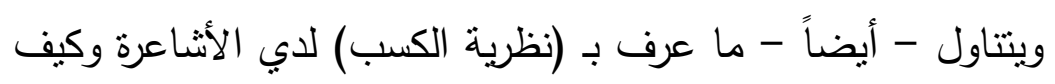

$$
\text { اعتبروها نظرية توفيقية وسطية بين الجبر والاختيار . }
$$

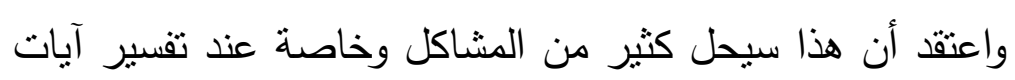

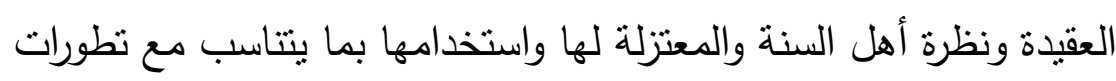
العلم الحديث وصياغتها في قالب جديد يتماشي مع الاكتثافات الكونية وعطاء النص القرآني المجيد وتضيين هوة الخلاف والثقاق بين أصحاب في في الاكي 
المذاهب المختلفة في تتاولهم لتقسير القرآن الكريم وتتاول مباحث علوم القرآن واضافة ما يستلزمه الواقع المعاصر .

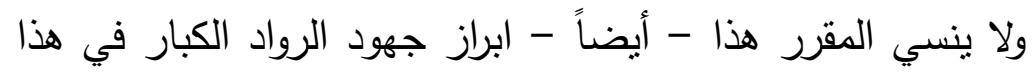
المجال وفي مقدنهم الإمام أبو الحسن الأشعري والماتريدي والقاضي الباقلاني، وإمام الحرمين الجويني والغزالي وغيرهم مع اثـارة إلي آية فروق قد تكون موجودة بين أشعرية المشرق والمغرب. (') كل هذا المقرر الذي سمي "بالايمان والعقيدة" هو ما يحتاج إليه المفسر والدارس والباحث في علوم القرآن حتي يخرج من القالب القديم ويستطيع أن يقدم خدمة جديدة يمكن أن تستخدم في تقسير القرآن وابراز عطاء الوحي الالهي للبشرية التي ما زالت تتخبط في غياهب الجهل والركون إلي النمط القديم والعيش أسيرة للماضي وتجاهل تطور العلم وواقع الناس وزيادة الكمية المعرفية (المعلوماتية) التي أضيفت للعلم وخاصة في القرن العشرين وظهور شبكة المعلومات الدولية المعروفة بـ (الثبكة العنكبوتية) أو مايسمي اختصاراً بـ (الانترنت) واستخدامه الرهيبة التي يمكن ان تستخل في نشر صحيح الدين من عقيدة وشربعة وأخلاق وسهولة التواصل بين الناس في شتي أنحاء المعدورة. المقرد الرابع: القرآن وعلم الاجتماع الإيني: هذا المقرر علي جانب كثير من الأهمية حيث يتتاول الجانب الاجتماعي أو الواقع الذي يطبق فيه الدين أي - علاقة الدين بالمجتمع حيث يتتاسي البعض طبيعة المجتمع الذي يطبق فيه الدين وخاصة ما 
يكون في المجتمعات البدائية أو المتحضرة - أو المجنمع ذو الثقافة

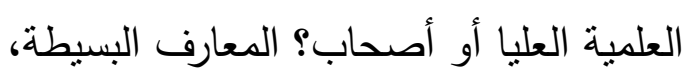

وهذا علي خطورته وأهميته يُلزم المجددون في التقسير - خاصة -

والدراسات القرآنية عامة بفهم طبيعة وخصائص المجتمع وظروفه وأهدافه

حتي يأتي التقسير متسقاً مع واقع المجتمع.

ويهنم (علم الاجتماع) عموماً بدراسة المجتمع كنسق منظم للعلاقات الاجتماعية ، ودراسة التفاعل الاجتماعي بين الأفراد ، والجماعات، والطبقات الاجتماعية المختلفة.

اما علم الاجتماع الديني - تحديداً - فيدرس في رأي المنظرين له له اله الهيه تأثثر الدين في المجتمع والثقافة والثخصية ، كما أنه بحسب اعثقادهم، بدرس عدداً من الموضوعات منل : وظيفة الطقوس الدينية في المجتمع وتصنيف التتظيمات الدينية ، واستجابة هذه التنظيمات للنظام الاجتماعي العام، وأثز الحركات الدينية في المجتمع، والاجابة علي السؤال الاساس في علم الاجتماع الايني وهو : ما هي العناصر السوسيولوجية والثثافية في الدين، ولذا لكل دين خصوصياته التي يضفيها بالضرورة ، علي علم الاجتماع الديني عند المشتغل به - كل بحسب عقيدته الدينية - سواء يهودية أو مسيحية أو هندوسية أو ليبرالية.

ولذلك أثرنا عدم استعمال عنوان (علم الاجتماع الاسلامي) وأثنتنا فقط مرجعيته إلي القرآن الكريم. وهذا المقرر يمكننا من فهم وظيفة الطقوس الدينية ن عقيدة وشريعة

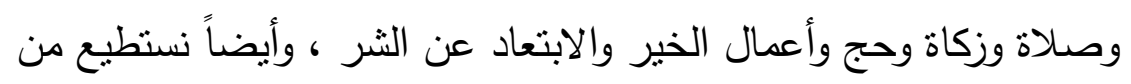

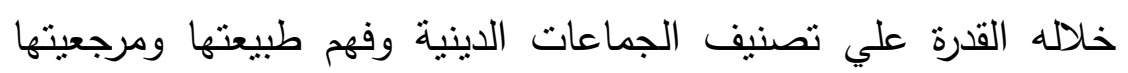


وتفسيراتها للدين كالسلفية (الدعوية - الجهادية - النكفيرية) وجماعة الاخوان المسلمين (الارهابية) وجماعات التكفير والهجرة وتتظيم الإرهابي ، وجماعة بوكوحرام في نيجيربا وجبهة النصرة وفتح الثام وجماعة أبو سياف في الفلبين والثيعة في بلاد ايران والعراق واليمن

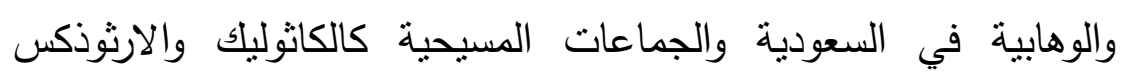
والبروكسانت، والتظيمات اليهودية مثل اللوبي الصهيوني في امريكا وحزب (اسرائيل بيتتا) في فلسطين الممنلة كل هذا يوقفنا علي دور الدين في المجتمع وأثزه وبناء أفكار صحيحة أو هدامية في المجتمع بنتج عنها نشر الأمن والأمان والرخاء أو بث الرهب واء والقبت والقتل والتدمير في نفوس الناس. ونري أن هذا المقرر يشتمل علي الافكار أو الموضوعات الرئيسية الآتية: (1) القرآن وبناء المجتمع علي أساس من القيم القرآنية بوضع مفهوم (الأمة) في القرآن وابراز القيمة الجامعة لمعني الأمة الاسلامية وخيرتها وتحميلها الرسالة من رب العالمين إلي قيام الساعة.

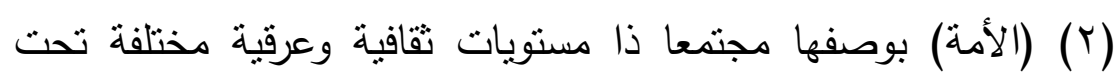
مظلة منظومة واحدة التي يشكل (التوحيد) درة عقدها.

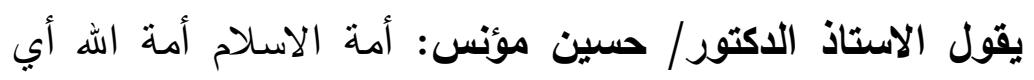

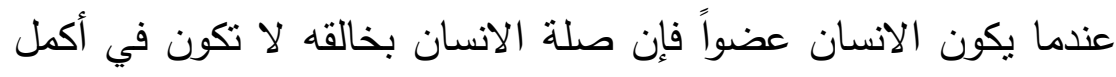
صورها إلا عن طريق الأمة، أب في جماعة المسلمين المعتصمة بحبل الله. لأن الاسلام ذروة رسالات الله للبشر ، ورسول الاسلام ذروة الكمال الانساني ، لأن الأمة هي حصن الاسلام ومعقل الايمان (').

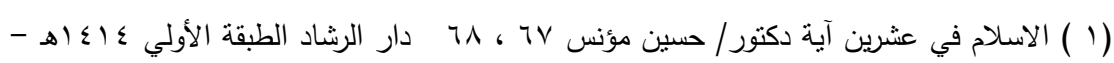


وعندما نتحدث عن الأمة فمن الخير أن نستقبل حقيقتتا الانسانية

$$
\text { كما هي: }
$$

فما اتصل بالعقل صقلناه بما يناسب من علوم.

وما اتصل بالقلب زكيناه بما يلائمه من تربية دينية ونصائح ايمانية.

وما اتصل بالجسد تعهدناه بما يتطلبه من زاد وعافية. (')

(r) مفهوم (العمران) في القرآن، ودوره، وغايته وهدفه في إعمار الكون واستمراره إلي قيام الساعة (هو أنثأكم من الأرض واستعمركم فيها)

هود / $71 / 4$

(§) (بناء الاسرة) في القرآن، ودورها، وغايتها عن طريق الزواج الثرعي في إطار من القيم الأخلاقية.

(0) الاتصال الجماعي Social contact في القرآن الاتجاهات والقيم والأدوار (النظام الجمعي) قال الله تعالي \}وإنك لعلي خلف عظيمي

$$
\text { القثم/ع (1) }
$$

(7) التكامل الاجتماعي Social Integration في القرآن الانماط المعيارية، والعمليات الرافعية والتوازن الوظيفي بمعني احتياج الأفراد

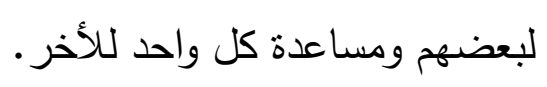

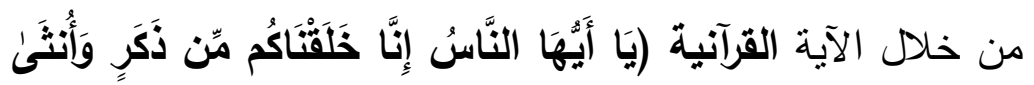

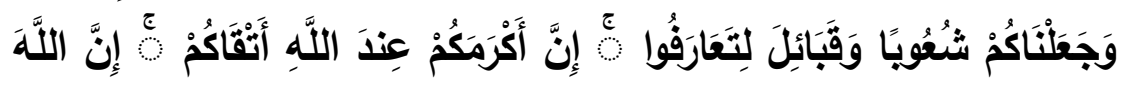

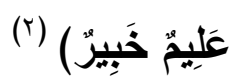

( ) ركائز الايمان بين العقل والقلب الثيخ/ محمد الغزالي صش؟ طبقة دار الثروق - مهرجان

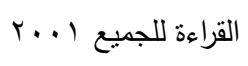

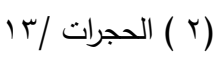


كنموذج للانطلاق في دراسة علاقات المجتمع الاسلامي مع بعضه ومع غيره من المجتمعات الانسانية المجاورة. Social control الضبط الاجنماعي (V) والقتل والزنا وقذف المحصنات والربا... إلخ العقبات الثرعية والقانونية والعرفية لضبط حياة المجتمع. (^) الضبط الذاتي Self - Control الامتثال للمعايير بوحي من

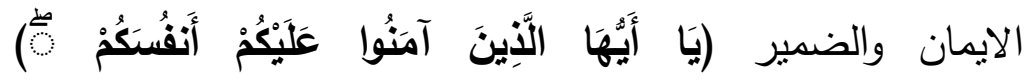
المائدة/ الأمان/ القوامة الاجتماعية: الوالي - الفقيه - المحتسب - الزوج - مفهوم

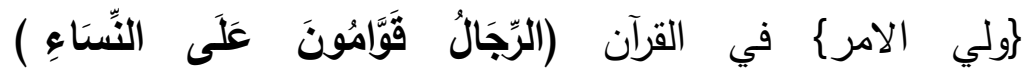

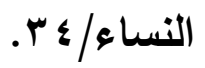
( ( ) اصلاح \}ذات البين\{ في القرآن وعلم (فض المنازعات) والمحافظة علي السلامة النفسية للمجتمع. (فإثقو الله وأصلحوا ذات بينكم)

(الانفال(ب)

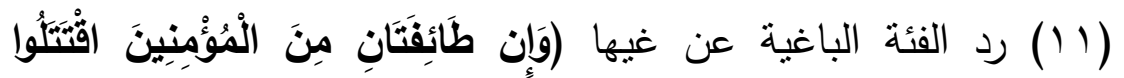

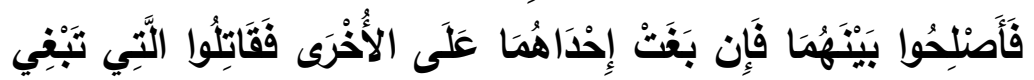

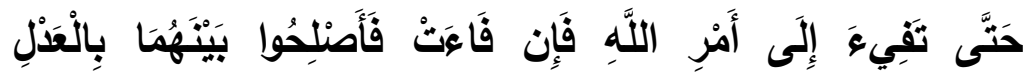

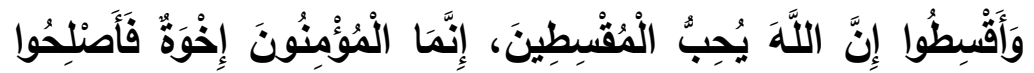

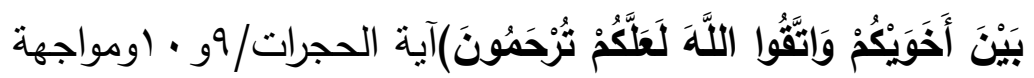
الظلم في القرآن. 


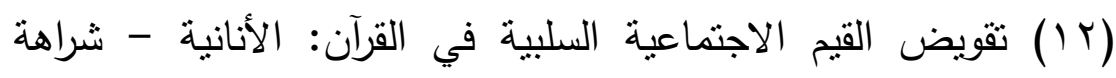

التملك - إغماء حق اليتيم والمسكين والسائل.

(T) الزكاة: تزكية رأس المال الفردي والجماعي في القرآن (قل اللهم مالك الملك تؤتي الملك من تشاء وتتزع الملك ممن تشاء)

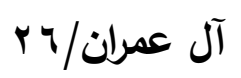

(ع () الصدقات: ودورها في تقليص ظاهرة الفقر والحد من العوز

$$
\text { والحاجة. }
$$

(0 10) مفهوم البر وصلة الرحم في القرآن (التفاعل المجتمعي) ( )

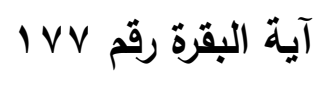

(7 (1) نظام المواريث في القرآن وعناية القرآن بهذا الجانب الاجتماعي

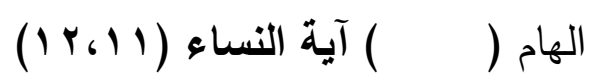

هذا المقرر قد يكون فيه ابراز لجانب - كما قلنا - علي قدر كبير من الأهمية لأنه يتمنت في اسقاط وانزال قيم الدين الخالدة علي واقع المجتمع الاسلامي ومعايثة الناس لهذه القيم الخالدة الضابطة لحركة

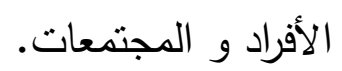


المقرر الخامس: القرآن ومشكلات العالم المعاصر:

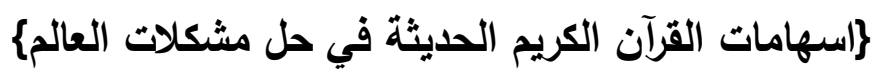

هذا هو ما يمكن أن ننطلق به لمخاطبة العالم المعاصر ويكون

للإسلام والمسلمين وجوداً ملحوظاً وقوياً علي الساحة العالمية التي لهاني لا تعترف إلا بالاقوباء.

وهذا المقرر يمكن أن يتتاول مشكلات العالم المعاصر ، وأكثر حدة

وتأثيراً، ويؤسس للحلول التي أقرها القرآن ضمنا لمعالجة هذه المشكلات انطلاقا من روح القرآن ومبادئه، ومعرفته بأمراض النفس وأهوائها، وأدواء العقول والغرائز ، أفراداً وجماعات. ويشتمل علي الشكل التالي: (1) هل هناك عقيدة للنطور (النمو إلي الخلف) والرجوع إلي آدم أبو البشر وتفكيك نظرية (دارون) (r) مسألة عولمة القيم (العولمة بكافة أنواعها السياسية والاقتصادية)

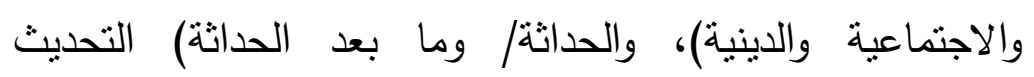

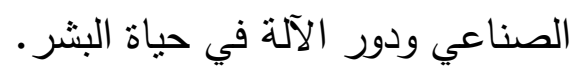

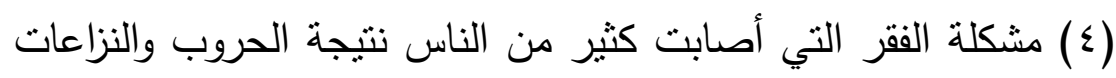
الإقليمية ، والفتن الطائفية والصراعات الإجتماعية والفروق الطبقية. (0) مشكلة المرض وظهور أنواع جديدة من الأمراض تفوق امكانيات البشر أحياناً.

(7) مشكلة تدمير البيئة وتبوير الأراضي الزراعية وتلوث المياه وضعف

$$
\text { الصرف الصحي. }
$$

مشكلة السوق الاحتكاري وتسلط بعض الدول علي مواد التصنيع (V) وبراءات الاختراع كما في أوربا وأمريكا وشرق آسيا. 
(^) مشكلة الصراع العرقي والطائفي بين الثيعة وأهل السنة بين أصحاب

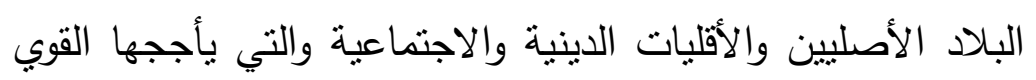

$$
\text { الاستعمارية والعناصر التخريبية. }
$$

(9) مشكلة السيطرة ذات القطب الواحد (الاختلال في توازن القوي)

$$
\text { والانفراد بقرار العالم واحتكار شرطي العالم. }
$$

(·) (1) مشكلة تهميش الحاجة الروحية (النزعة الدينية والفطرة الانسانية)

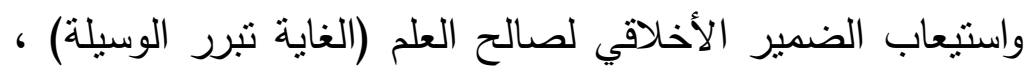

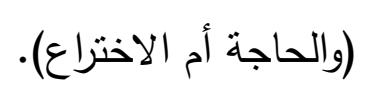

(1) (1) مشكلة العنف الدولي والمحلي والاسري والفردي بكل أنواعه ونتائجه

$$
\text { الرهيبة علي الجميع. }
$$

(r ( ) مشكلة التفكلك الاسري وانهيار سلطة الآب في المنزل واعتداءات

$$
\text { الأولاد علي الآباء وضياع الأجيال، وانهيار الأخلاق. }
$$

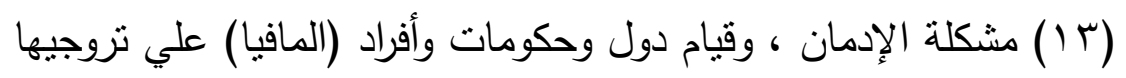

$$
\text { وحمايتها ، وتحريم الاسلام لكل المسكرات. }
$$

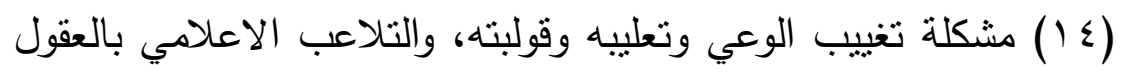

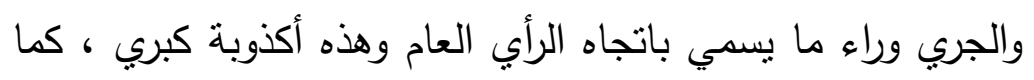

$$
\text { يؤكد ذللك علماء الاعلام. }
$$

(1 (1) مشكلة المجتمع السلعي المستهلك، وغواية الاعلان.

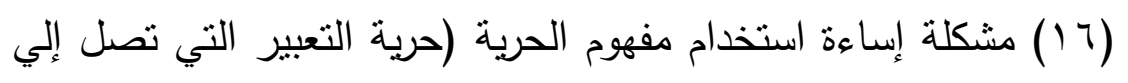

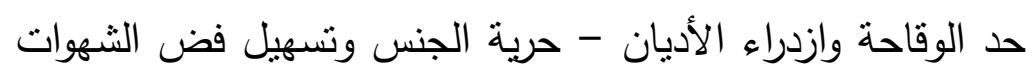
وحرية الكسب وعدم التعويل علي الحلال والحرام ....إلخ).

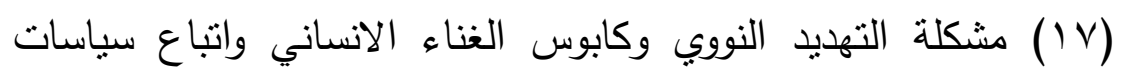
الردع النووية وصرف مقدرات الثعوب علي النسليح. 
وتكديس الالات الحربية. مع ذكر قضية التدافع بين الناس (ولولا

دفع الله الناس بعضهم ببعض لهامت صوامع وييع وصلوات ومساجد

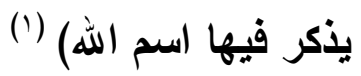

وتأني مقاربات القرآن لموضوعات عامة يحتاج إليها العالم

$$
\text { المعاصر في هذه الأيام ومنها: }
$$

التطور - الرفاهية - سلامة الجسد - المحافظة علي توامان

الطبيعة - وظيفة الثزوة - القسمة العادلة - السلام الاجتماعي والدولي -

اعلاء النزعة الروحية والنفسية - ترشيد الضمير الأخلاقي للعلم - لـاعية استئصال العنف - يقظة العقل وغيابه - نبذا الغش والكذب - محاولة الرغبة الاستهلاكية عند الانسان - الحرية وشروطها - تفويض جنون القوة - القضاء علي احتمالات تدمير العمران علي الأرض. كل هذا هو ما يحتاجه العالم اليوم من المسلمين ولا يحتاج منهم العناه تقسيم العالم إلي دار إسلام ودار حرب ، لا يحتاج إلي قتل المسيحيين وتدمير كنائسه، لا يحتاج إلي ارهاب المسلمين في شتي بلاد العالم،

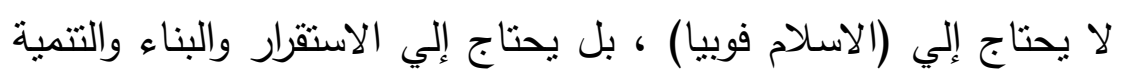
والتعامل الطيب والجدال بالتي هي أحسن كما قال تعالي "ولا تجادلوا أهل الكتاب إلا بالتي هي أحسن إلا الذين ظلموا وقالوا أمنا بالذي أنزل إلينا وانزل إليكم واللهنا والاهكم واحد ونحن له مسلمون" (؟) وانطلاقا من قوله إله تعالي " ادع إلي سبيل ريك بالحكمة والموعظة الحسنة وجادلهم بالتي

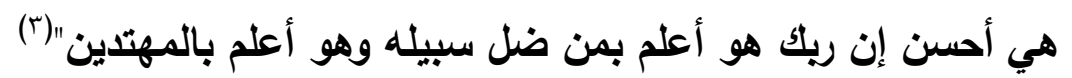




\section{الخاتمة}

بعد حمد اله تعالي في البداء والمنتهي ثم الصلاة علي النبي المصطفي وبعد هذه الجولة الطيبة في مجال تجديد الخطاب الديني وخاصة (التجديد في مجال التفسير وعلوم القرآن والدراسات القرآنية).

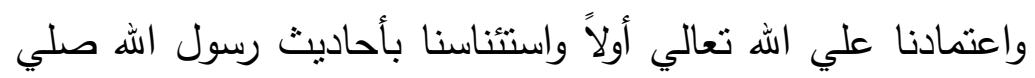

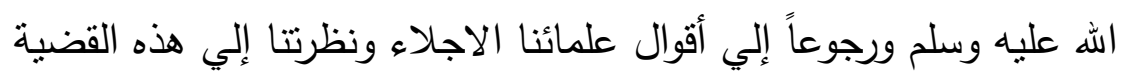
ورؤينتا لما نتتمي أن يكون عليه التجديد في مجال التفسير وعلوم القرآن.

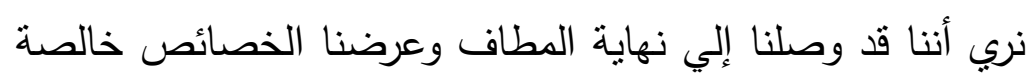

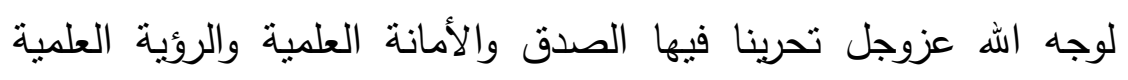
والنظرة المسنقبلية وكان هدفنا اخراج جيل جديد يعرف قيمة القرآن ، ايجاد

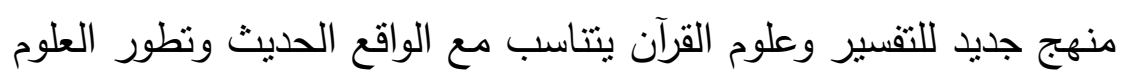
والاكتشافات العلمية الجديدة. فإن كنا قد وصلنا إلي هذه النتيجة فالحمد لله رب العالمين

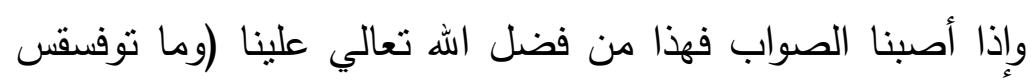
إلا باله عليه توكلت وهو رب العش العظيم)

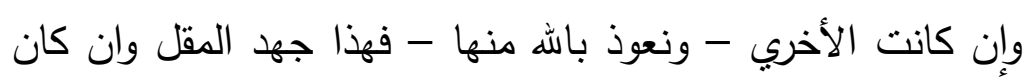

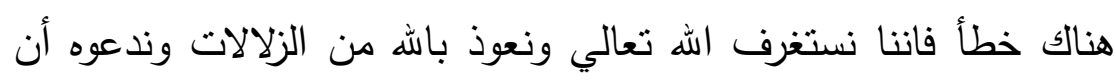
يلهمنا الصواب ويعفو عن الزلات، إنه ولي ذلك والقادر عليه. 
القرآن الكربح:

المراجع مرتبة حسب الترتيب الأبجدي بدون "الأف واللام"

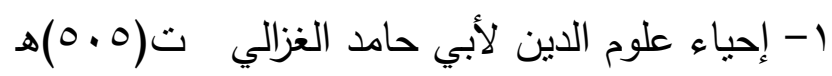

r- أزمات الانسانية والحل القرآني أ.د/ طه جابر العلواني هدية هيئة

كبار العلماء مجلة الازهر الثريف - شهر ذي الحجة VTـ

r- الإسلام في عشرين آية أ.د/ حسين مؤنس - دار الرشاد - الطبقة

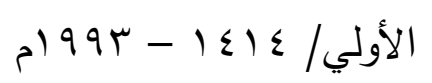

ع- أقوال محمد بن كعب القرظي في التفسير د/ محمد إبراهيم أحمد رجب رسالة ماجستير (غير منشورة) كلية أصول الدين والدعوة

$$
\text { بالمنصورة - جامعة الأزهر V V. . بام. }
$$

0- الإكسير في علم التفسير - الطوفي - بدون تاريخ.

7- تذكرة الحفاظ لإِمام الذهبي.

V- تفسير القرطبي للامام القرطبي دار الغد العربي الطبعة الثالثة

$$
\text { ه) } 5.9-1919
$$

9- تهذيب التهذيب ابن كثير الدمثقي.

• 1- التقسير الكبير للإمام الرازي المسمي (مفاتيح الغيب)

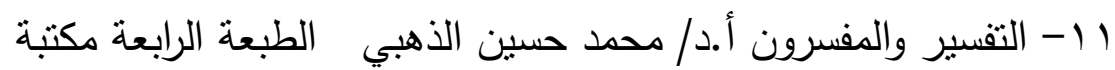

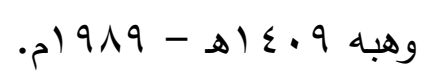

r ا - تقسير المنار محمد رشيد رضا - بدون تاريخ با - ركائز الإيمان بين العقل والقلب - الثيخ / محمد الغزالي طبعة دار

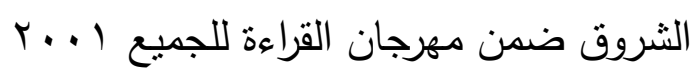

$$
\begin{aligned}
& \text { - أبو داود } \\
& \text { ء ا - سنن أبي داود }
\end{aligned}
$$




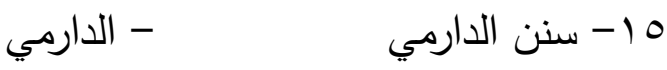

$$
\begin{aligned}
& 7 \text { ا } 17
\end{aligned}
$$

I - فضائل القرآن ابن سلام تحقيق: مروان العطية - محسن خرابة وفاء تقي الدين دار ابن كثير دمشت / بيروت

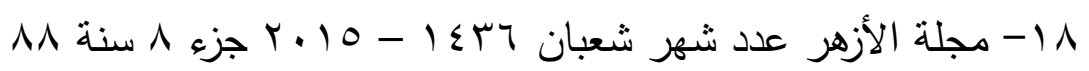
9 19 - مجلة الازهر عدد ذي القعدة وذي الحجة بسءاهـ - اكتوبر (10 10 • r- المستدرك لأبي عبد الله الحاكم ا اب- المصطلح الأصولي د/فريد الأنصاري. r بr - مفتاح العلوم السكاكي. ؟ ז- المقاصد الحسنة السخاوي. هץ- مقدم في أصول التفسير ابن تيمية. جr- موسوعة الإعلام الزركلي. 